\title{
Explaining the Constitutional Integration and Resurgence of Traditional Political Institutions in Sub-Saharan Africa
}

\author{
Forthcoming in Political Studies
}

\author{
Katharina Holzinger \\ University of Konstanz
}

\author{
Florian G. Kern* \\ University of Essex
}

\author{
Daniela Kromrey \\ University of Konstanz
}

\begin{abstract}
Social scientists have recently observed a "resurgence" of traditional political institutions on the constitutional level in Sub-Sahara Africa. Yet, the scope and causes of the resurgence remain unclear. We base our analysis on original data on the degree of constitutional integration of traditional institutions and on their constitutional resurgence since 1990 in 45 countries of Sub-Saharan Africa. We test six theoretical explanations for constitutionalization: former colonial rule, democratization, state capacity, economic development, foreign aid and settlement patterns. First, we verify the broad resurgence of traditional political institutions on a constitutional level. Second, our analysis suggests that, particularly in former British colonies, traditional leaders were able to translate the arrangements of British colonial rule as well as the advantages of a country's deconcentrated settlement pattern into greater constitutional status. Third, settlement patterns proved important for traditional leaders to gain or increase constitutional status - leading to a constitutional resurgence of traditional institutions.
\end{abstract}

Key Words: constitution, integration, resurgence, Sub-Saharan Africa, traditional political institutions

Word count: 11.270 (incl. tables, footnotes, references) 


\section{Biographical information:}

Katharina Holzinger is chair of International Politics at the Department of Politics and Public Administration at the University of Konstanz, Germany. Her research areas include the European Union, environmental policy, negotiation and deliberation, and traditional governance and indigenous peoples. She has published in journals such as International Organization, Comparative Political Studies, European Journal of International Relations, Political Communication, Journal of European Public Policy, European Union Politics, and with Cambridge University Press.

Florian G. Kern is a Lecturer (Assistant Professor) at the Department of Government, University of Essex. He received his $\mathrm{PhD}$ in Politics and Public Administration from the University of Konstanz in 2016. His research focuses on the comparative politics of informal and indigenous governance and related effects. His work has been recently published in Research \& Politics, Political Research Quarterly, and the Journal of Mixed Methods Research.

Daniela Kromrey is Programme Director for Internationalization at the Zukunftskolleg - Institute for Advanced Study at the University of Konstanz. She has received her $\mathrm{PhD}$ in Politics and Public Administration from the University of Konstanz in 2016. Her current research focuses on traditional political systems, democratization, legacies of freedom fighters in Africa and survey research. She has published in journals such as Journal of Peace Research, African Affairs and Political Research Quarterly.

\section{Acknowledgements:}

We thank Federica Genovese, Thomas Malang and the reviewers for Political Studies for their invaluable comments and critique. In addition, Florian G. Kern thanks the German Academic Exchange Service (DAAD) for their support, as well as Francis Fukuyama and colleagues at the Center on Democracy, Development, and the Rule of Law (CDDRL) at Stanford University for providing an inspiring research environment during parts of this research. Daniela Kromrey acknowledges the support of the Friedrich Ebert Foundation.

\section{Funding:}

We thank the German Foundation for Peace Research (Grant No. PA 003/11-Nr.005/12-2010) and the German Research Foundation (Grant No. HO 1811/10-1) for providing funding for this research. 


\section{INTRODUCTION}

In many states in Sub-Saharan Africa, ethnic groups organize their political decision-making, their conflict resolution, or land rights via traditional political institutions (TPI). TPI co-exist with the institutions of the state. This type of co-existence is not limited to Sub-Saharan Africa but can be found across the globe (Holzinger, Kern and Kromrey, 2016, 470), with an estimated 57 percent of the world population living in countries where customary and other forms of law exist in parallel (JuriGlobe 2019). Moreover, TPI are also an important factor shaping various political issues and outcomes, ranging from the provision of public goods (Baldwin 2015, 2019; Goist and Kern 2019), economic development (Acemoglu, Reed and Robinson, 2014), democracy and elections (Baldwin 2013, 2014, 2019; Baldwin and Holzinger 2019; Baldwin and Mvukiyehe 2015; de Kadt and Larreguy 2018; Koter 2013), or peace and conflict (Wig and Kromrey 2017; Mustasilta 2019). The interaction of TPI and the state plays a crucial part in these outcomes, especially where their agendas collide.

While the existence of TPI is a worldwide phenomenon, for Sub-Saharan Africa in particular, several scholars have identified a "resurgence" of TPI in recent years (e.g. Englebert 2002a; Erk 2014; Logan 2009; Ubink 2008). The Afrobarometer surveys reveal that constituents continue to consider TPI important and express a desire for a greater political role of traditional leaders (Logan 2013). Authors also find that TPI become increasingly codified in constitutions, implying recognition by the state (Holzinger et al. 2019). Yet, evidence for the constitutional resurgence of TPI is mostly based on case analysis. The scope and the conditions for the alleged resurgence remain unclear.

In this paper, we therefore analyse the constitutional integration of TPI and their resurgence comparatively across all Sub-Saharan countries to systematically examine the conditions leading to the current constitutional regulation of TPI. We define constitutional integration as the degree of codified recognition of TPI in a country's constitutional documents, and constitutional 
resurgence as the increasing degree of constitutional integration of TPI. We code the most recent and the Sub-Saharan constitutions in 1990 with respect to their provisions on TPI. Our data confirm the resurgence of TPI on a constitutional level. Using a fuzzy-set Qualitative Comparative Analysis (fsQCA) we find that, particularly in former British colonies, traditional leaders were able to translate the arrangements of indirect rule as well as the political advantages of a country's deconcentrated settlement patterns into greater constitutional status. Moreover, the latter element has remained important for traditional leaders to increase constitutional status implying a constitutional resurgence of TPI.

\section{THE RESURGENCE OF TPI IN CONTEMPORARY SUB-SAHARAN AFRICA}

\subsection{Literature on resurgence of TPI}

The coexistence of state and TPI in Sub-Saharan Africa's political arenas has long been recognized (e.g. Mamdani 1996; Buur and Kyed 2007; Megisteab and Hagg 2017). While numerous studies have investigated traditional governance and its role (Holzinger, Kern and Kromrey 2016 provide a comprehensive overview), we briefly hint at some recent examples: Scholars of legal pluralism in Africa have described the different ways states incorporate customary law in their legal frameworks (e.g. Ubink 2008; Muriaas 2009). For Zambia and Sub-Saharan Africa in general, Baldwin shows the contemporary roles of TPI, e.g. in public goods provision and electoral outcomes $(2013,2015,2019)$. Hariri's (2012) focuses on how strong, proto-state precolonial institutions have led to an autocratic legacy in many non-European countries. For a sample of 33 former British colonies, Lange (2004) finds that indirect rule via customary authorities has a strongly negative effect on measures such as bureaucratic effectiveness, political stability or the rule of law. Looking at electoral politics in South Africa, de Kadt and Larreguy (2018) show how chiefs' alignment with the incumbent party (African National Congress) improves the latter's electoral performance. Finally, for communities in the Democratic Republic of Congo, van der Windt et al. (2019) find that citizens' support for TPI and the state can go 
hand in hand in a complementary fashion: where support for the state increases, so does support of TPI.

Yet, none of these studies comprehensively explains the varying constitutional status of TPI in Sub-Saharan Africa or attempts to analyse the observed resurgence of TPI in comparative perspective. A number of scholars have identified a "resurgence" of traditional authority starting in the 1990s. Sklar (1999) reviews the role of TPI in the constitutions and politics of a small number of African countries. He concludes that many African polities are characterized by mixed government, i.e. cooperative interaction among distinct and relatively autonomous governmental institutions involving the state and TPI. According to Sklar, the institutionalization of mixed government has somewhat increased in the 1990s. Englebert (2002a) points to the variance of resurgence across the continent - manifest e.g. in legal-institutional arrangements such as national houses of chiefs in Ghana, Botswana, South Africa and Namibia. Yet, when examining which factors determine the variance in the resurgence, he asserts that no clear picture emerges.

Explicit references to a resurgence of traditional authority can also be found in Boone's study on land tenure reforms in Africa and the involvement of neo-traditional institutions (2007), Erk's mapping of the resurgence of TPI as one of five evolutionary patterns in African decentralization (2014), as well as in Ubink's work on the general resurgence of TPI in Africa (2008). In her argumentation, "resurgence" appears to be two-fold: first, a comeback of a stronger legal recognition of traditional authority by African national governments; and second, an increased interest of the academic community to study the dynamics of traditional leadership within the modern nation-state. In a similar fashion, Nabudere (2004) maintains that because of the dysfunctional nation-state in Sub-Saharan Africa, TPI have "resurged" across the region.

Englebert (2002b) looks at the "born-again" Buganda Kingdom in Uganda. The latter has reemerged in the 1990s with increased social significance and granted legal roles in the constitu- 
tion. For South Africa, Oomen and van Kessel (1997) depict the "constitutionalization" of traditional authority, and Koelble and LiPuma (2011) find traditional leaders to have resurged as intermediaries between the state and society. Yet, Beall et al. (2005) do not see resurgence, but rather persistence of TPI in South Africa. Finally, Baldwin (2014) finds that traditional chiefs in Zambia have seen their responsibility in land administration increase and argues that this is because political leaders cede control of land resources to traditional leaders of non-co-ethnic groups in exchange for mobilising electoral support in such communities.

\subsection{Namibia as a paradigmatic case of resurgence}

Namibia serves as an example for a resurgence of TPI. Today, TPI in Namibia are strongly integrated into state structures on the constitutional and legal level. The Namibian constitution of 1990 acknowledges TPI in regard to two aspects: First, article 66(1) recognizes customary law as one of Namibia's sources of law. Traditional authorities, who feature in customary law, are thus implicitly acknowledged by the constitution. Second, article 102(5) presupposes the existence of traditional authorities, as it allows for the establishment of a Council of Traditional Leaders that advises the president on all matters of interest to traditional authorities (Hinz 2008, 66). Beyond constitutional recognition, there are a number of laws and statutes which regulate the relationship of traditional and state institutions. ${ }^{1}$ One of the key pieces of legislation is the 2000 Traditional Authority Act which provides for the formal establishment of traditional authorities and outlines their responsibilities, functions, and duties. According to the Act, chiefs have to be installed by their traditional community and have to be officially recognized by the state. Until now, around 50 traditional authorities have been recognized and are given a financial allowance by the state (Holzinger, Kern and Kromrey 2017). 1997; Traditional Authority Act 2000 replacing the former Traditional Authority Act of 1995; Community Courts Act, 2003. 
The current high degree of constitutional integration of TPI has its roots in colonial rule. During German colonial rule (since 1884) and the following South African Apartheid regime (since 1949), traditional leaders were used as local governing agents in a system of indirect rule in the North, whereas in the South a more direct rule was implemented by the Germans. Precolonially, the northern Kingdoms, such as Ovambo, Kaoko, or Kavango, were in possession of land with their kings taking decisions on the allocation of agricultural land among community members. The southern headmenships, like the Damara, Nama or San, with their nomadic life-style, did not own territory. During colonialism these differences were fortified with the erection of the veterinary cordon fence (for a detailed historical account cf. Lechler and McNamee 2018). Still today, the northern traditional institutions are stronger and more hierarchically organized (cf. Hinz 2008). Lechler and McNamee show that this even affects attitudes towards democracy today, with people north of the fence being less supportive of democracy.

After independence from South Africa, a process of "re-appropriation of tradition" (Hinz $2008,68)$ started in 1990. A presidential commission of enquiry was set up in 1991, with the task to provide information about the de facto roles and functions of traditional authorities and their acceptance by the people. The commission concluded "that the traditional system is not only necessary but also viable" and "recommends that it be retained within the context of the provisions of the Constitution of the Republic of Nambia" (cited in Hinz 2008, 70). In 1992, a national meeting of politicians, legal experts and traditional leaders initiated the process of ordinary law development.

The subsequent Traditional Authority Act (2000) stipulated regulations for all Namibian TPI based on the hierarchical model of the northern kingdoms which led to a convergence of traditional authority structures in the country (Holzinger, Kern and Kromrey 2017). This might be explained by the stronger presence of the northern kingdoms in the processes of law development. The governing SWAPO (South West Africa People's Organisation) had its origins as 
liberation movement "Ovamboland People's Organisation" and thus drew on stronger links with the northern Ovambo kings (Düsing 2002: 123ff.; Welz und Kromrey 2015).

It is important to note that only those TPI with traditional land could be recognized, transferring the existence of communal land into a basis of traditional power (Behr, Haer and Kromrey 2015). Consequently, demands for land rights and claims for kingships emerged during the early 1990s (Düsing 2002: 128ff.). This way TPIs became more relevant in the rural areas of Namibia, in particular the northern kingdoms, but also in the south. During the 1990s Namibia was highly deconcentrated, with a number of smaller regional centers. Almost 70 percent of the Namibian population resided in rural areas. Local government structures were weak, however, as the newly democratic state still struggled to build up local state capacity. Therefore, as Düsing states: "[t]he impact of traditional leadership, as quasi local government bodies and agencies of rural development in these areas, cannot be underestimated" $(2002,241)$ and "they still remain the only local level institution to fill the gap left by a largely absent state" $(2002,243)$. Land allocation and rural development are seen as the most important function of TPI and traditional leaders are still widely accepted in rural communities and often more so than regional councilors (Keulder 1997; Düsing 2002: 243ff.). This led to parallel political structures in rural areas.

In sum, the following factors seem to have contributed to the constitutional and legal resurgence of TPI in Namibia: A colonial system of indirect rule allowed for TPI to uphold a strong political role. After independence, TPI could maintain this role, in particular in the highly populated rural areas because of the weakness of the state at regional and local level. Finally, in the newly developing democracy they were able to effectively exert demand for legal recognition. 


\section{THEORY AND HYPOTHESES}

Scholars employ at least three distinct conceptions of the resurgence of TPI. First, resurgence can be understood as an increase of the perceived social-political importance that African constituents ascribe to traditional leaders. The Afrobarometer provides comparative data for 19 countries in round 4 (2008), and for 33 countries in round 6 (2014-15). For the countries included in both rounds, "trust in traditional leaders" has increased by 5 percent on average between 2008 and 2015. Second, resurgence might be understood as the increase of actual political influence of traditional leaders in a country. This type of resurgence is more difficult to uncover and is mostly observed in case studies. Third, resurgence can be understood as the increasing degree of constitutional integration of TPI (see Sklar 1999).

We focus on the latter definition. To be sure, constitutional arrangements and their changes are not by themselves a direct measure of the varying power of TPI. At times, constitutions can appear as mere written rules that only partially reflect political realities. Constitutions may e.g. include progressive rules on issues such as gender equality even if in practice societies adhere to opposing norms. Aware of these limitations, we however argue that measuring the social influence of TPI by focusing on variance in their constitutionalization is a valid empirical strategy for at least three reasons:

First, and more generally, constitutions are ubiquitous and can be found in all countries across Sub-Saharan Africa. This allows us to include a larger sample of countries in our sample as compared to relying e.g. on survey data from the Afrobarometer, which does not include as many countries. ${ }^{2}$

Round 4 of the Afrobarometer includes public opinion data for only 19 countries of Sub-Saharan Africa, compared to 45 countries in our sample. Moreover, round 4 of the Afrobarometer is the first with a battery on attitudes about traditional leader and was collected for 2008/2009. There is unfortunately no comprehensive public opinion data prior or close to our baseline data for 1990, and thus we cannot infer whether there has been a change in public opinion over time in support for TPI leading to a change in constitutional law. That said, our additional analyses (not included here and only for the 19 countries surveyed in round 4) showed positive correlations between our measure of contemporary constitutional integration and items measuring public support for TPI. 
Second, changing a constitution always involves high institutional hurdles. As similarly argued by Elgie (2012) or Tsebelis and Nardi (2014), a changed constitution "had serious shortcomings and $[\ldots]$ overwhelming majorities understood and suffered from these shortcomings" (Tsbelis and Nardi 2014, 11). Successful changes in the constitution therefore reflect a previous mismatch between the constitutional document and social realities on the ground - either in the eyes of the constitution-makers or the constituency as a whole. A change in the constitution seeks to amend this mismatch e.g. by increasing the constitutional powers of TPI, or by curtailing the rights of TPI compared to the previous constitution.

Third, a change in the constitution may also represent an increased awareness of an issue that constitution-makers need to incorporate as a signal to a relevant audience. Thus, even if in reality changes are slow to manifest, the recognition of the importance of such rights and acknowledgements can serve as a future reference point to the affected population. To be sure, the motivations for constitutional changes we observe may vary: a government may want to accommodate TPI by granting increased rights to them or strive for more control over traditional leadership by further defining their role constitutionally or by excluding TPI from any constitutional rights. Legally integrated TPI may even lose power compared to a situation of informal coexistence with the state - a case in point is Uganda, where the constitutionalization of traditional leaders in 1995 implied taking away their right to participate in partisan politics. At the very least, a change in the constitutional integration of TPI (a resurgence or a dismantling of rights) is an important signal by the constitution-makers that the issue of TPI and their role in the political sphere cannot be ignored.

Englebert (2002a) puts forward four possible explanations of traditional resurgence: "state strength", or the capacity of state institutions; democratization on the country-level; the domestic economic situation; and "external and facilitating material factors". The latter include very

However, given the limited sample, we only take this as pointing to a possible link between public opinion and constitutional law rather than evidence of causation. 
different factors such as pressures from the development community, or ratification of international treaties. Englebert discusses evidence for correlations but does not present empirical tests, and in fact is cautious in his interpretation of causal relationships and directions of effects. In our study, we include the "theoretical speculations" Englebert suggests (2002a, 55) and add two further factors that we deem particularly important: colonial legacies and settlement patterns.

Analysing constitutional "resurgence" implies comparison across time. Because authors argue that TPI have been increasingly constitutionalized since the 1990s, we compare two points in time in order to track the change (the constitutional text in 1990 and the most recent constitution, with 2012 as the cut-off point for our coding). We look at two different outcomes: the current constitutional status of TPI and its change since 1990. Explaining both status and change of the constitutional integration of TPI requires the distinction of causes that may have status-related and change-related effects. In the following, we discuss the explanatory factors and present separate hypotheses on one or both of our outcomes. Status-related hypotheses are subscripted with a $t$, while change-related hypotheses are subscripted with a $\Delta t$.

\subsection{Legacies of colonial rule and administration}

The effect of past colonial administration on constitutional arrangements only shapes the status of constitutional integration of TPI, as the variable does not change after independence or 1990. ${ }^{3}$ During colonization in Africa, two approaches can be distinguished: first, direct rule, usually associated with French authorities; and second, indirect rule, commonly associated with British authorities. In the French system, traditional structures were preferably abolished or assimilated, while the British would attempt to include traditional systems within their hierarchies of rule (Young 1994, 149ff.) and often granted them a legal status by decrees or similar

While in some countries colonial power changed before independence, for the time-period of interest (1990 until today), colonial legacy is fixed. 
documents. We thus expect that former British colonies are more likely to include TPI in their constitutions after independence (cf. Englebert 2002a, 56). While colonial approaches may have varied depending on local contexts (Boone 1998, 15-16), one can assume that path dependencies of these policies have left their mark in later constitutional texts. If chiefs had a strong administrative role during colonial rule, they might have been able to leverage an equally strong formalized role after independence. ${ }^{4}$ As British and French were not the only colonial powers in Sub-Saharan Africa, we simplify by discerning British and non-British colonies. This leads to the following hypothesis:

\section{H1: British colonial rule before independence leads to a high level of constitutional integration of TPI.}

\subsection{Deconcentrated settlement patterns}

TPI can be assumed to be more significant in rural territories because remoteness and ethnic homogeneity of communities should allow TPI to retain a strong role in the lives of constituents. The dynamics should be similar in smaller but ethnically homogenous cities that form regional sub-centres, where personal contact with TPI and community members is frequent. In contrast, in large metropolized areas, the heterogeneous ethnic environment together with the impact of modern individualistic life-style will weaken individuals' social ties to their place of origin and the TPI there. Thus, deconcentrated settlement patterns can be indicative of societal modernization. Deconcentrated settlement patterns in a country, i.e. a relatively small population living in very large urban centres (metropolises) as compared to those living in a higher number of small cities, should affect social significance of TPI and political demand for constitutionalization. Thus, the more concentrated the population is in metropolitan areas, the less significant should be TPI, and the less constitutional integration we expect to observe. Consequently, an

Equally, one might presume that chiefs who were collaborators under colonial rule were not included in post-colonial constitutional arrangements. 
increase in metropolization should lead to decreased socio-political significance of traditional leaders, and a weaker constitutional role of TPI.

H2t: A deconcentrated settlement pattern (i.e. low metropolization) leads to a high level of constitutional integration of TPI.

H2 ${ }_{\Delta t}:$ A concentration in settlement patterns (i.e. an increase in metropolization) leads to a decrease in the level of constitutional integration of TPI.

\subsection{Level of democracy and democratization}

A democratic state ideally accommodates heterogeneous interests of its constituents, e.g. by granting cultural rights to ethnic groups or minorities. A democracy should thus be more prone to respond to demands for constitutional status of such special group rights. Thus, we expect a more democratic state to display a higher status of constitutional integration of TPI. The level of democratic performance of a state might change over time. A state may democratize, or its political institutions may become more autocratic, possibly leading to a change of the constitutional integration of TPI over time. Thus, we expect a democratizing state to exhibit an increase of the constitutional integration of TPI (cf. Englebert 2002a, 58). The following two hypotheses describe both causal mechanisms:

$H 3_{t}$ : A high level of democracy leads to a high level of constitutional integration of TPI.

$H 3_{\Delta t}$ : Democratization leads to an increase in the level of constitutional integration of $T P I$.

\subsection{State capacity}

Another argument presumes TPI are particularly strong in states where governments are weak (cf. Englebert 2002a, 56). The mechanism relating weak state capacity and the constitutional integration of TPI may run in two directions. First, the constitutional integration of TPI may 
enable governments to administer remote areas of the territory through them. Second, the constitutional inclusion of TPI might be a way to appease constituents in those regions. Thus, a country with low state capacity might display greater levels of constitutional integration of TPI. Again, state capacity may be subject to change over time. If state capacity increases, the constitutional integration of TPI might decrease. The subsequent hypotheses reflect this argumentation:

H4t: Low state capacity leads to a high level of constitutional integration of TPI.

H4 $4_{\Delta t}$ : A decrease in state capacity leads to an increase in the level of constitutional integration of TPI.

\subsection{Economic development}

The level of economic development of a country may shape how states include TPI in their constitutions. Poor economic opportunities for constituents may go hand-in-hand with more informal subsistence-based economies. The latter are more likely to provide a greater role to traditional leaders as arbiters in these markets, e.g. in terms of granting access to land via traditional tenure rules, or traditional control over natural resource access and use. The increased leverage of TPI in informal economic transactions translates into constitutional integration in case governments acknowledge that local economic prosperity depends on traditional rules and actors. Thus, in countries with low levels of economic opportunity, one might expect constitutional integration of TPI. Further, economic performance may change over time, and countries may see an amelioration or deterioration of economic development and opportunities.

H5: A low level of economic development leads to a high level of constitutional integration of TPI.

H5 $5_{\Delta t}$ : A decrease in the level of economic development leads to an increase in the level of constitutional integration of TPI. 


\subsection{External factors: Foreign Aid}

Finally, Englebert (2002a) discusses external and facilitating material factors. We suggest that the tying of foreign aid to constitutional reform by international financial institutions during the 1990s and beyond (as a consequence of the so-called Washington Consensus) could have stimulated the constitutionalization of many factors, among them TPI. Change in official development assistance (ODA) could therefore also lead to the constitutional integration of TPI by conditionality, e.g. by demands for greater deconcentration of power or more participatory politics.

\section{H6 $6_{\Delta t}$ : An increase in the level of official development assistance leads to an increase in the level of constitutional integration of TPI.}

\section{METHOD AND DATA}

We do not assume the six potential explanations as individually sufficient to cause constitutional integration or resurgence. Rather, the causal factors complement each other and work in conjuncture. We assume that combinations of several conditions may explain the outcome, and furthermore, that different combinations might have the same effect on the constitutional status of TPI or a change of it. This leads us to employ Qualitative Comparative Analysis.

\subsection{Fuzzy Set Qualitative Comparative Analysis (fsQCA)}

QCA uses a conception of causality that captures more than one causal pathway to an observed outcome and examines different combinations of causal conditions (Rihoux and Ragin 2009, 8-10). In QCA, necessary and sufficient causal conditions are distinguished. A causal condition is necessary for the outcome if the condition is present in all instances the outcome is observed. A causal condition is sufficient for the outcome if the outcome is present in all instances the causal condition is observed (Ragin 2000, 100). Taken strictly, this conception implies that finding single cases that do not fit the causal pathway should lead us to reject our hypothesis. 
However, as deterministic relationships are rare in the social sciences, Ragin proposes using benchmarks for "coverage" and for "consistency" to assess the hypotheses and explanatory power of different "solutions". The solution formula describes the combination of conditions that lead to a given outcome. Coverage is the percentage of cases displaying the outcomes that are explained by a given solution formula (Schneider and Wagemann 2012, 119-150). Consistency, in turn, is the percentage of cases that are described by (are consistent with) the solution formula.

We choose fuzzy-set Qualitative Comparative Analysis (fsQCA) as the method of inference for three reasons. First, QCA allows for equifinality, that is, several causal paths can lead to the outcomes, the integration and resurgence of TPI. Second, as pointed out above, we expect combinations of several causal conditions to be particularly relevant - a methodological strength of QCA. Third, because our outcome is coded in four different categories along the dimension of how "integrative" the provisions in the constitutions are, i.e. how much TPI are integrated with the state political institutions, we use fuzzy-set QCA instead of crisp-set QCA. ${ }^{5}$ Moreover, pairwise correlations, cross-tabulations, and regression analysis have inferential limitations given our low number of observations - we analyse traditional resurgence in 45 Sub-Saharan African countries. Having outlined the reasons for choosing fsQCA to analyse the constitutional resurgence in Sub-Saharan Africa, we acknowledge the extensive methodological debate on the uses of QCA (e.g. Baumgartner and Thiem, 2015; Braumoeller 2017; Krogslund, Choi, and Poertner, 2015; Lucas and Szatrowski 2014; Munck 2016, Paine 2016; Ragin 2014; Ragin and Rihoux 2004; Rohlfing 2015; Schneider and Rohlfing 2016; Thiem 2014, 2017). ${ }^{6}$ Thus, we present additional statistical evidence to substantiate our findings.

5 We employed the widely used fs/QCA (Ragin, Drass and Davey 2006), as well as QCA pro (Thiem 2016), and SetMethods (Medzihorsky, Oana, Quaranta and Schneider 2016), to avoid false algorithmic routines that might distort our results.

6 See the debate within the American Political Science Association's Qualitative \& Multi-Method Research group, e.g. Newsletter (2014) vol. 12, no. 1 and no. 2. 
We do not expect to find necessary conditions for constitutional integration and resurgence, even if some authors find such relationships in the social sciences (Schneider and Wagemann $2007,41,60)$. We cannot imagine that the presence of integration or resurgence of TPI necessarily requires the presence of a British colonizer, a democracy, low state capacity or low levels of development. The only necessary condition might be the mere existence of TPI in a country - a condition we cannot test because there is no variation in our sample. We thus assume our potential explanations to be sufficient conditions, which jointly, not individually, bring about the outcomes.

\subsection{Operationalization, data sources, and calibration}

We compare the constitutional integration at two points in time: (1) the status quo in 1990, and (2) in the year of the most current constitution (2012). The outcome of current constitutional integration is the formal regulation of TPI in the most recent constitution of a country. For constitutional resurgence, we measure constitutional change that occurred between 1990 and the current constitution. For both points in time, we coded the constitutions of $45 \mathrm{Sub}$-Saharan countries. However, we have to drop Liberia and Somalia from the analysis, since no adequate data on the conditions could be obtained.

The application of fsQCA requires the calibration of the outcomes (integration, resurgence) and the causal conditions (colonial rule, deconcentrated settlement patterns, democratization, state capacity, economic development, official development assistance). That is, the variables need to be operationalized and mathematically transformed to an ordinal or continuous scale ranging between zero and one.

We coded both outcomes qualitatively from constitutional documents in force in 1990 and the most current constitution. The levels of integration can vary from the recognition of traditional values to the integration of traditional leaders in local or national state government structures. Thus, we distinguish four degrees of constitutional integration (see table 1). Recalling 
our hypotheses, a "high level of integration" corresponds to "integration" and "dualism", and a "low level of integration" corresponds to "tolerance" and "non-integration".

\section{Table 1 here.}

The following examples illustrate the ordinal categorizations. Tanzania does not make any provisions for the recognition of TPI (coded 0.0). Her most current constitution (1977, amended 2000) explicitly proclaims the unity of all citizens: "A citizen of the United Republic shall not have a right, status or special position on the basis of his lineage, tradition or descent" (Article 3). Constitutional non-integration of any traditional norms reflects Julius Nyerere's idea of African socialism, aiming at abolishing ethnic divisions and unifying all Tanzanians (Geschiere, Meyer, and Pels 2008). The Gabon constitution (1991, amended in 2003) acknowledges traditional values and culture in its preamble: "Proclame solennellement son attachement à ses valeurs sociales profondes et traditionnelles, à son patrimoine culturel, matériel et spirituel, au respect des libertés, des droits et des devoirs du citoyen" (coded 0.3). The 2004 Mozambique constitution represents a case of dualism of traditional and state authorities (coded 0.7). It not only promotes traditional values, but also "recognize[s] and esteem[s] traditional authority that is legitimate according to the people and to customary law" (Article 118). However, in contrast to states in the highest category, no official status for traditional leaders is granted, nor an official institutional setting established. In contrast, Ghana incorporates chieftaincies as political institutions in its 1992 constitution (amended 1996, Article 207) and even establishes a National House of Chiefs (Article 89) and is thus a highly integrative country (coded 1.0). 
To check the robustness of our coding we refer to a new dataset that codes provisions on TPI and customary law for all UN member state constitutions valid in $2014 .^{7}$ The data set provides simple counts of provisions and particular additive indices constructed from dichotomous coding. We test for the correlation of our outcome data and their most basic measures which capture our idea of the "extent of constitutional integration". Their count variable correlates highly significantly ( $\mathrm{p}$-value $=0.01$ ) at an $\mathrm{R}=0.8141$, and their basic index "acknowledgment" at an $\mathrm{R}=$ 0.8330 , which we take as a validation of robustness of our measurement.

We measure resurgence as the change of the constitutional integration value between 1990 and the most current constitution. This difference can take a negative value when we observe a dismantling of the legal status of TPI (e.g. from "dualism" to "non-integration"). An illustrative example for a strong resurgence is Cameroon. The constitution of 1984 did not mention traditional rulers or customary law (coded 0, "non-integration"). However, the 1996 constitution (amended 2008) establishes a right for traditional rulers to be represented in the Regional Councils and to be elected by their peers (coded 1.0 as "integration"). Similarly, the 1962 constitution of Uganda (active in 1990) and its subsequent amendments do not include traditional leaders, while the constitution of 1995 includes a whole chapter on traditional and cultural leaders that specifies their rights and in particular excludes them from political office. Both cases would be considered a constitutional resurgence of TPI.

We use the direct method of calibration in order to obtain fuzzy values for resurgence: fsQCA employs a logistic function to assign the fuzzy values from the raw data, given three qualitative anchors at 1 (full membership), 0.5 (point of indifference), and 0 (full non-membership) (Schneider and Wagemann 2012, 35-41). The direct method enables a fine-grained calibration without condensing the original data to categories and thus loses none of the original data's

\footnotetext{
We cannot compare this data to our 1990 coding, as it only captures the most recent date. The "TradGov Constitutional Data Set" was collected within the research project "Traditional Governance and Modern Statehood", funded by the German Research Foundation (DFG, No. HO 1811/10-1).
} 
empirical information. We set the anchor points based on theoretical considerations, defining the highest positive change value as 1.0 , the lowest value as 0.0 , and no change as point of indifference, i.e. 0.5 on the fuzzy scale.

For the explanations of resurgence, we use the conditions' values of 1989 and of the year before the adoption of the current constitution, this way lagging the conditions and allowing for elapsed time for a causal effect. Since the time between the 1990 constitution and the adoption of the most current constitution varies considerably across the countries, we normalize this difference, arriving at a measure of the average yearly change in the conditions. The anchors for resurgence are based on the distribution of the empirical data for both the outcome and all conditions.

We code the first condition, colonial rule, dichotomously. We distinguish between British and all other colonizers to capture the legacy of British indirect rule; before decolonization, a country was either under British rule (1.0) or under a non-British colonial power (0.0). We rely on the data of the "Quality of Government Institute". 8

For the second condition, the deconcentrated settlement pattern, we use metropolization (cf. Schulz 2015 for the concept) and not urbanization as an indicator. First, what counts as "urban" in absolute numbers varies widely across Sub-Sahara Africa rendering an absolute measure of urbanization incomparable. Second, measures of urbanization typically include also populations living in smaller cities, i.e. in the regional sub-centres of a country. However, we assume, as outlined in the theory section, that TPI may be strong in smaller but ethnically homogenous

\footnotetext{
See http://www.qog.pol.gu.se/data/datadownloads/qogstandarddata/. The QoG coding uses the last colonizer before independence; in cases with two colonizers for the contemporary territory of a state, the colonizer on the larger territory is used. Another measure of indirect rule is provided by Lange (2004), who codes the extent of indirect rule for 33 former British colonies (inside and outside Sub-Saharan Africa) by "dividing the number of colonially recognized customary court cases by the total number of court cases in 1955" (Lange 2004, 909). Our own analysis shows that our coding correlates highly and significantly with Lange's measure, and using the latter in our QCA leads to analogous results. Using Lange's measure yields slightly higher consistency values ( 0.87 compared to 0.83 with our measure) but with coverage losses ( 0.39 compared to 0.49 in our measure).
} 
cities that form regional sub-centres, where personal contact with TPI and community members is frequent. Therefore, we argue that a metropolization measure better proxies our idea of settlement concentration. ${ }^{9}$ It is defined as the population in the largest city as a percentage of urban population and serves as an indicator of the degree to which we find not only one urban centre but also regional sub-centres in a country, i.e. a deconcentrated settlement pattern. We calibrate the fuzzy scale such that full membership (1.0) is achieved if 75 percent, no membership $(0.0)$ if 25 percent, and cut-off $(0.5)$ if 50 percent of the urban population live in the largest city. We rely on data provided by the World Bank. ${ }^{10}$

For the calibration of all other conditions we again apply the direct method of calibration setting the anchor points theoretically. To operationalize the third condition, level of democracy, we use data from POLITY IV, with scores ranging from 10 (full democracy) to -10 (full autocracy). We set the anchor points for the QCA calibration at 9 for democracies (1.0) and -9 for non-democracies $(0.0)$. For the point of indifference ( 0.5 on the fuzzy scale) we use the POLITY score of 0.5 , this way interpreting all closed anocracies (0 to -5 POLITY score) as non-democratic.

We operationalize the fourth condition, state capacity, using data and the scale for government effectiveness provided by the Worldwide Governance Indicators (WGI). ${ }^{11}$ For the direct calibration, we employ the original scale, ranging between -2 and 2 , with zero as the point of indifference.

We use GDP per capita to operationalize economic development (World Bank data). We calibrate as follows: full membership (1.0) is achieved with values of 4000 US Dollars and

9 We ran the QCA model also with urbanization as a measure. It leads to similar results, although the coverage and consistency values are better for metropolization. Metropolization explains more cases, in particular for resurgence. See annex, tables A25-A27 for details.

10 See http://databank.worldbank.org/data/home.aspx

11 Data by the International Country Risk Guide data are only available for 30 out of the 45 SubSaharan countries, see https://www.prsgroup.com/explore-our-products/international-countryrisk-guide/. 
above, no membership (0.0) with values of 500 US Dollars and below, and the cut-off point $(0.5)$ is set at a value of 1500 US Dollars.

Finally, to operationalize foreign aid we use data from the $\mathrm{OECD}^{12}$ measuring the share of official development assistance in the respective countries' Gross National Income (GNI). As we test hypothesis 6 only for resurgence, we do not use the direct calibration method for integration. We set the anchors for resurgence based on the empirical distribution of the data, just as for the other conditions (see above).

\section{ANALYSIS AND FINDINGS}

We first provide descriptive evidence of the constitutional integration and the resurgence of TPI. Subsequently, we analyse the necessary and sufficient conditions for the outcomes "integration" and "resurgence". ${ }^{13}$

\subsection{Description of constitutional integration}

We start with an overview on the extent of the constitutional integration of TPI in the year 1990 and the current constitutions. Table 2 demonstrates that almost 50 percent of countries in SubSaharan Africa provided constitutional status for TPI in 1990. Today, the corresponding figure is close to 75 percent. Thus, we observe an increase of constitutional integration, overall confirming a constitutional resurgence across countries. We also find that the rise is particularly strong with respect to the acceptance of a "dualism" of state and TPI. Moreover, many states moved away from "non-integration" of traditional values, rights or authorities.

See https://data.oecd.org/oda/net-oda.htm

While we follow Schneider and Wagemann (2010) to first analyze the necessary, then the sufficient conditions, we do not interrelate the two steps as proposed by their Theory-Guided/Enhanced Standard Analysis (T/ESA). That is, we do not bar remainders that are incompatible with the results of the first stage from being used as simplifying assumptions by the Quine-McCluskey algorithm. We agree with Baumgartner (2015) that only parsimonious solutions (including all both positive and contradiction minterms) generate methodologically correct solutions. 


\section{Table 2 here.}

Table 3 further illustrates the extent of the constitutional resurgence of TPI. We observe an increase in constitutional status in 16 countries, i.e. in more than one third of our sample: Angola, Burkina Faso, Burundi, Cameroon, Chad, Ethiopia, Gabon, Madagascar, Mozambique, Niger, Rwanda, Somalia, South Africa, Sudan, Togo and Uganda. In more than half of the countries nothing changed in the constitutions with respect to TPI. Finally, there were six countries, which reduced the rights of TPI: Central African Republic, the Comoros, Djibouti, Equatorial Guinea, Nigeria and Senegal.

\section{Table 3 here.}

These results validate observations by Englebert (2002a) and others: a resurgence of TPI has occurred on the constitutional level since the 1990s. One third of countries incorporated rules regarding TPI into their constitutions, or strengthened existing rules. The observation must be qualified, however, as twelve countries continue to have no constitutional regulation at all.

\subsection{Analysis of integration}

Necessary conditions. We turn now to the analysis of necessary conditions for constitutional integration (see tables A2.1 and A2.2 in the annex). Following Schneider and Wagemann (2010), we first analyse potential necessity for all conditions separately. Empirically, none of the conditions reaches the standard for a necessary condition of a consistency value of 0.90 or higher. This is true for both the presence and the absence of constitutional integration, in line with our expectations.

Sufficient conditions. By analysing sufficient conditions, we test whether the presence or absence of a certain condition or a combination of conditions is sufficient to cause integration. 
Table A1 in the annex contains the truth table showing all 32 logically possible combinations of the five causal conditions and their empirical occurrence. We observe empirical instances for only 11 combinations, i.e. there are 21 logical remainders lacking empirical cases. We do not make assumptions on whether logical remainders lead to the absence or presence of the outcome, because our theory is not strong enough to do so. In consequence, we include all logical remainders in the analysis and present the so-called parsimonious solutions (Baumgartner 2015). Nevertheless, we also report the complex solution in the Supplemental Annex (Tables A3 and A4), which excludes all possible counterfactuals in the minimization process for the sake of transparency and completeness (Wagemann and Schneider 2012).

\section{Table 4 here.}

The parsimonious solution consists of only two conditions, British colonial rule and the absence of metropolization (Table 4). The other three conditions appear inconsistently only in the complex solutions (Table A3 in the Supplemental Annex) - sometimes presence, and sometimes absence contributes to integration. ${ }^{14}$ The overall consistency of the parsimonious solution is satisfactory (0.82), but covers only 48 percent of states.

Conditions that are part of both parsimonious and complex solutions (or that are uniformly present across various solutions) can be considered "core elements" indicating a "strong" relationship with the outcome (Rihoux and Marx 2013). We can thus conclude that British colonial rule and a deconcentrated settlement pattern (low metropolization) contribute to the explanation

14 Running the analysis for the absence of the outcome, i.e. non-integration, supports this finding. See annex, table A4 and A5. For robustness, we also ran the analysis excluding the condition state capacity, which reduces the number of logical remainders. All solutions produce the same solution term, i.e. exactly the parsimonious solution as presented above. See annex, table A6 for details. 
of constitutional integration of TPI. We cannot provide satisfactory evidence for effects of democracy, state capacity and economic development. ${ }^{15}$ The medium coverage indicates, however, that our explanation might be incomplete and missing other important factor(s).

In order to substantiate our findings, we employ standard statistical techniques. The results of correlation analysis and an ordered logit regression based on the un-calibrated data are similar to the findings of the QCA (Tables A13 and A14 in the Supplemental Annex). Metropolization correlates significantly, weakly and negatively $(-0.44$, p-value 0.01$)$ and British rule correlates significantly and positively $(0.42, \mathrm{p}$-value 0.01$)$ with integration. The ordered logit model likewise shows a negative, significant effect for metropolization and a positive, significant effect for British rule on integration. However, explained variance is low $\left(\mathrm{R}^{2}=0.30\right)$ and the interaction term of metropolization and British rule is not significant. Metropolization is still significantly negative in the interaction model, which could indicate deconcentrated settlement patterns are the most important explanation for constitutional integration.

A closer look at the countries covered reveals that Botswana, Ghana, Lesotho, Malawi, Namibia, Sierra Leone, South Africa, Swaziland, Zambia, Zimbabwe are typical cases for the solution path, i.e. they exhibit a low level of metropolization, are former British colonies, and have a high level of constitutional integration of TPI. Sudan, Uganda, Kenya and Nigeria display a lower level of integration but a similar causal direction. Thus, about half of all countries recognizing TPI (integration or dualism) were subject to British colonial rule and exhibit a high level of deconcentrated settlement pattern (low metropolization). The QCA reveals that it is the conjunction of both conditions that explains integration - separately, neither British colonial administration, nor low metropolization are necessary or sufficient for the constitutional integration of TPI. robustness check. The results are overall similar and the values for consistency $(0.85)$ and coverage (0.65) are even improved. See annex, tables A7 through A9 for details. 
Based on this finding, we would expect former British colonies with deconcentrated settlement patterns such as Mauritius and Tanzania to equally strongly integrate TPI. Yet, they show low values of constitutional integration. Reasons unaccounted for by our theory led these countries to constitutionally ignore TPI. Regarding Tanzania, the establishment of Ujamaa reforms and the corresponding side-lining of TPI might be reasons for the country's deviance. Mauritius is a special case, because it was colonized by the Portuguese, the Dutch, the French and the British, and had no indigenous population before colonization. The current population consists predominantly of people from Indian and Creole origin (cf. Tinker 1977).

Fifteen countries show neither the solution path nor the outcome and are thus consistent with the theory. Finally, twelve countries show the outcome but not the solution path and remain thus unexplained: Angola, Burkina Faso, Cameroon, Chad, DRC, Ethiopia, Gambia, Madagascar, Mozambique, Niger, Rwanda and Togo.

\subsection{Analysis of resurgence}

In the analysis of constitutional resurgence, we run two models. For the first model, we use three conditions: democratization, change in deconcentrated settlement patterns, and change in economic development. Colonial rule did not change after the year 1990. State capacity data is unavailable for 1990 (or 1989). For these conditions we are thus unable to calculate the change over time. ${ }^{16}$ For the second model, we add change in official development assistance as the forth condition. Our sample for both models consists of 42 countries of which 15 experienced a resurgence, six a constitutional dismantling, and half of the sample (21) remain unchanged with respect to TPI. ${ }^{17}$ Two of the variables exhibit skewed distributions: democratization and-

16 Moreover, the exclusion of state capacity from the analysis of integration did not change the results (see annex, table A6). In addition, to control for alternative explanations we tested for internal conflict as a condition for resurgence. Conflict does not appear in any solution (see annex, tables A28-A30).

17 We had to drop Benin because its 1990 constitution is also the most current one and we can thus not analyze change. 
to some degree - resurgence. Consequently, we increase the consistency thresholds in the analyses.

Necessary conditions. We do not find any necessary conditions for resurgence. ${ }^{18}$ Closest to a single necessary condition is democratization. However, it is almost necessary for both the presence $(0.875)$ and the absence $(0.898)$ of the outcome. Moreover, in the compound analysis all conjunctions include democratization (see Tables A15.1 and A15.2 in the Supplemental Annex). We can interpret democratization as a background condition that is not causally related, as most countries in the sample experienced some democratization since 1990.

Sufficient conditions. With three conditions (model 1), we have eight potential combinations to trigger resurgence. Two combinations have no empirical cases, i.e. there are two logical remainders (see truth table A16 in the Supplemental Annex). With four conditions (model 2), we have 16 potential combinations of which six are logical remainders (see truth table A31 in the Supplemental Annex $)^{19}$. In both models, we make no assumptions about logical remainders. We display the parsimonious solution.

The parsimonious solution of our first model shows that either a decrease in metropolization or an autocratization explain resurgence. However, causal paths including autocratization have very low unique coverage values. Only two countries in the sample experience autocratization (Eritrea and Gambia) and both exhibit no change (0.5) in the constitutional status of TPI. We can therefore neglect autocratization and focus on the core element of all solutions, the decrease in metropolization. ${ }^{20}$

Table 5 here.

This result stays robust after omission of the 21 countries which did not change the constitutional status of TPI. See Supplemental Annex, Tables A20 through A22 for details.

19 The large share of logical remainders (6 out of 16) results from the skewed distribution of democratization, i.e. we hardly observe negative trends in democratization.

20 Running the analysis for the absence of the outcome, i.e. constitutional dismantling/non-resurgence, again supports these findings. See Table A18 and A19 in the Supplemental Annex. 
The latter appears consistently through all robustness checks. We first calculate a model excluding countries not experiencing a change of the constitutional status of their TPI, and second, calculate a crisp-set analysis in order to account for the skewedness of democratization (see annex, Tables A20 through A24 in the Supplemental Annex). The solutions in all robustness checks are similar to those above, without solution paths including autocratization, however.

\section{Table 6 here.}

For the second model, we find a similar result: either a decrease in metropolization in combination with an increase in development assistance, or autocratization explain resurgence (Table 6). While this solution is more consistent, coverage is reduced compared to the model without aid (see Tables A31-A33 in the Supplemental Annex). That is, official development assistance seems to play a role in conjunction with metropolization: constitutionalization appears most in countries that decentralize and receive aid after 1990.

In a final test, we exclude democratization as a condition and end up with the familiar path of a decrease in metropolization in all solutions (see Table A34 in the Supplemental Annex) for model 1, and the interaction of decreased metropolization and increased aid for model 2 (Table A35 in the Supplemental Annex). This leads us to conclude that the settlement structure has indeed greatest explanatory power.

It seems that a decrease in metropolization - implying deconcentration of settlement patterns - prompts constitutional resurgence. In contrast, democratization is not causally linked to resurgence of TPI. Although coverage levels are much better compared to constitutional integration, the model for resurgence could still be improved in terms of explanatory power. This is confirmed by the statistical analysis (see Tables A36 and A37 in the Supplemental Annex). The 
correlation of metropolization and resurgence is negative as expected, but weak and non-significant. Likewise, the regression analysis exhibits a negative, but non-significant relationship of metropolization and resurgence. ${ }^{21}$

Seven countries (Angola, Chad, Ethiopia, Madagascar, Mozambique, Rwanda and Uganda) are typical cases for the solution path, i.e. they experience an increase in deconcentrated settlement together with strong constitutional resurgence, whereas Burundi and Gabon display only weak resurgence. The Central African Republic and Equatorial Guinea do not show the outcome although they meet the core solution. Finally, there are six unexplained cases: Burkina Faso, Cameroon, Niger, South Africa, Sudan and Togo exhibit resurgence but not the solution path. There must have been factors not connected to the settlement pattern that led these countries to constitutionalize TPI. Just as in the case of constitutional integration there is room for further explanatory conditions. For South Africa, for example, the end of the apartheid brought a new constitution including TPI in 1996.

Our study attempts to provide an aggregate, comparative picture of integration and resurgence of TPI. While an in-depth qualitative investigation is beyond the scope of this paper, further unpacking some of the typical cases above helps illustrate the argument we make about the mechanisms at play linking a deconcentration of settlement patterns (or decreasing metropolization) to a constitutional resurgence of TPI. For instance, typical cases such as Mozambique or Uganda have experienced changes in the deconcentration of settlement patterns in the time period of our analysis (since 1990) through diffused urbanisation and population movements in each country. In practice, this meant that additional urban centres emerged besides the largest city, equivalent to a decrease in metropolization captured in our models. The emergence of new urban centres was triggered by critical junctures in the trajectory of each state: In Uganda displacement of populations because of repeated episodes of violence within by the normalization to average yearly change from an ordinal to a discrete measure. 
and in bordering countries has deconcentrated local settlement patterns and led to further urban agglomerations emerging. Moreover, towns such as Gulu in Uganda have been growing as "humanitarian hotspots" given interventions of external actors (Büscher et al. 2018). For Mozambique, which ended its civil war in 1992, Kirshner and Power (2015) describe in detail how the resource boom and related investment has led to further sub-boom towns emerging.

According to our theory, the constitutional resurgence of TPI in both countries in the same time period reflects the emergence of these new urban power centres and changes in settlement patters. While urbanised, these new centres are smaller in size and possibly remain ethnically more homogenous, providing traditional leaders with the leverage to become local power brokers, which may translate into greater constitutional powers for them. When adopted in 2004, the constitution of Mozambique clearly recognizes traditional leaders as legitimate in the eyes of the people and based on customary law (Art. 118). In Uganda, the constitutional resurgence in 2005 showcases an attempt to further define the role of cultural leaders which had already been recognised in 1995.

\section{SUMMARY AND DISCUSSION}

In this article, we provide the first comparative, cross-country empirical evidence for the constitutional resurgence of TPI since the 1990s in Sub-Sahara Africa. We show that constitutions today indeed include more regulations for TPI than in the year 1990. Compared to about 50 percent in 1990, today almost 75 percent of states have constitutional status for TPI.

Explaining the current constitutional integration of TPI, we find support for two of our conditions: the combination of British colonial rule before independence and a high level of deconcentration in settlement patterns is sufficient for a high level of constitutional integration. We find no consistent support for the three other conditions: democracy, state capacity, and economic development. 
Regarding constitutional resurgence since 1990, we find only one causal factor. A deconcentration of settlement patterns, i.e. reduced metropolization, is sufficient for the resurgence of TPI. Democratization, economic development, or foreign aid do not seem to have a consistent impact. As most Sub-Saharan states have democratized during our observation period, democratization comes close to a necessary condition, but is not sufficient to explain a constitutional resurgence of TPI.

The roles of British colonial rule and deconcentrated settlement patterns can be similarly interpreted: Following British indirect rule traditional leaders may have been able to leverage their colonial status into constitutional integration. Low metropolization is equivalent to deconcentrated settlement patterns. In such a setup there is more leverage for TPI to exert political influence as compared to metropolized, ethnically heterogeneous settlement patterns. In conclusion, British colonial rule and deconcentrated settlement patterns - or even an increase of the latter in recent times - may have enabled TPI to achieve constitutional integration. These results thus speak to findings by de Kadt and Larreguy (2018), Lange (2004) and others regarding how colonial policies have shaped the social importance of TPI in contemporary politics. However, our findings also expand on this argument, showing that settlement patterns can further determine how much leverage TPI can generate in order to increase their constitutional status. More generally, where the political geography of a country allows for sub-centres to emerge (instead of a single metropolitan centre), one may expect TPI with more constitutional powers, and possibly with greater effects on the various political issues and outcomes (development, democracy, and conflict) shown by the growing literature on TPI.

We see two avenues for further research. First, single or comparative case studies may further determine the causal relationships identified by the fsQCA. We have started to describe the causal mechanisms at play for a resurgence based on our theoretical framework and existing literature, but original and more targeted data collection could provide more specific observa- 
tions. Typical cases such as Botswana, Ghana, and South Africa for integration, and Mozambique, Rwanda, or Uganda for resurgence can inform analyses about the relationship of changes in settlement patterns, a decline in metropolization and the constitutional resurgence of TPI.

Second, our explanations may be expanded. The results for both outcomes are consistent and only very few cases that meet the causal conditions show neither constitutional integration nor resurgence. For both outcomes, however, we find a number of unexplained cases. Since other conditions we tested do not appear in consistent ways in the solution formulas, we conclude that the explanation is incomplete and there should be additional factors responsible for granting TPI constitutional status. Potential additional explanations for constitutional integration might include the ethnic composition of a country, or the internal organization of the ethnic groups (powerful kingdoms or weaker kinship groups). For these conditions, data was unavailable, and testing them would require further extensive original data collection.

For constitutional resurgence, the distribution of political power might play a decisive role: powerful chiefs can lend electoral support or legitimacy to politicians and parties seeking power, and they can demand constitutional status in exchange. Weak governments may seek the support of TPI and offer legal recognition or even an institutional role in the state polity. Since these circumstances vary case-by-case, process tracing would be needed to determine their effects.

\section{References}

Acemoglu, Daron, Tristan Reed, and James A. Robinson. 2014. "Chiefs: Economic Development and Elite Control of Civil Society in Sierra Leone.” Journal of Political Economy 122, 2: 319-68.

Baldwin, Kate. 2013. "Why Vote with the Chief? Political Connections and Public Goods Provision in Zambia." American Journal of Political Science 57, 4: 794-809. 
Baldwin, Kate. 2014. "When Politicians Cede Control of Resources: Land, Chiefs, and CoalitionBuilding in Africa." Comparative Politics 46, 3: 253-271.

Baldwin, Kate. 2015. The Paradox of Traditional Chiefs in Democratic Africa. Cambridge: Cambridge University Press.

Baldwin, Kate. 2019. "Elected MPs, Traditional Chiefs, and Local Public Goods: Evidence on the Role of Leaders in Co-Production From Rural Zambia.“ Comparative Political Studies 52, 12: 1925 1956.

Baldwin, Kate and Katharina Holzinger. 2019. "Traditional Political Institutions and Democracy: Reassessing their Compatibility and Accountability." Comparative Political Studies 52, 12: 17471774.

Baldwin K and Mvukiyehe E. 2015. "Elections and Collective Action: Evidence from Changes in Traditional Institutions in Liberia." World Politics 6, 4: 690-725.

Baumgartner, Michael. 2015. "Parsimony and Causality." Quality \& Quantity 49, 2: 839-856.

Baumgartner, Michael, and Alrik Thiem. 2015. "Model Ambiguities in Configurational Comparative Research.” Sociological Methods \& Research: doi:10.1177/0049124115610351.

Beall, Jo, Sibongiseni Mkhize, and Shahid Vawda. 2005. "Emergent Democracy and 'Resurgent' Tradition. Institutions, Chieftaincy and Transition in KwaZulu-Natal." Journal of Southern African Studies 31, 4: 755-771.

Behr, Daniela, Roos Haer and Daniela Kromrey. 2015. "What is a Chief without Land? Impact of Land Reforms on Power Structures in Namibia.” Regional \& Federal Studies 25, 5: 455-472.

Boone, Catherine. 1998. "State Building in the African Countryside. Structure and Politics at the Grassroots." Journal of Development Studies 34, 4: 1-31.

Boone, Catherine. 2007. "Property and Constitutional Order: Land Tenure Reform and the Future of the African State." African Affairs 106/425, 557-586.

Braumoeller, Bear F. 2017. "Aggregation Bias and the Analysis of Necessary and Sufficient Conditions in fsQCA." Sociological Methods \& Research 46, 2: 242-251.

Büscher, Karen. "African cities and violent conflict: the urban dimension of conflict and post conflict dynamics in Central and Eastern Africa." Journal of Eastern African Studies 12(2), 193-210.

Buur, Lars, and Helene Maria Kyed. eds. 2007. State Recognition and Democratization in Sub-Saharan Africa a New Dawn for Traditional Authorities? New York, N.Y.: Palgrave Macmillan.

de Kadt, Daniel and Horacio A. Larreguy. 2018. "Agents of the Regime? Traditional Leaders and Electoral Politics in South Africa." The Journal of Politics 80, 2: 382-399.

Düsing, Sandra. 2002. Traditional Leadership and Democratisation in Southern Africa. A Comparative Study of Botswana, Namibia, and South Africa. Hamburg: LIT. 
Elgie, R. (2012), "Exogenous Political Institutions? Constitutional Choice in Postindependence Francophone Sub-Saharan Africa", Political Research Quarterly 65, 4: 771-783.

Englebert, Pierre. 2002a. "Patterns and Theories of Traditional Resurgence in Tropical Africa." Mondes en développement, 30: 51-64.

Englebert, Pierre. 2002b. "Born-again Buganda or the Limits of Traditional Resurgence in Africa." Journal of Modern African Studies 40, 3: 345-368.

Erk, Jan. 2014. "Federalism and Decentralization in Sub-Saharan Africa: Five Patterns of Evolution." Regional \& Federal Studies 24, 5: 535-552.

Geschiere, Peter, Meyer, Birgit, and Peter Pels. 2008. Readings in Modernity in Africa. London: James Currey.

Goist, Mitchell, and Florian G. Kern. "Traditional institutions and social cooperation: Experimental evidence from the Buganda Kingdom.” Research \& Politics 5, 1: 1-9.

Hariri, Jacob G. 2012. "The Autocratic Legacy of Early Statehood.” American Political Science Review 106(3): 471-494.

Hinz, Manfred O. 2008. Traditional Governance and African Customary Law: Comparative Observations from a Namibian Persepctive, in: Horn, Nico and Anton Bösl: Human Rights and the Rule of Law in Namibia, Windhoek, Namibia: Konrad Adenauer-Stiftung, pp. 59-88.

Holzinger, Katharina, Roos Haer, Axel Bayer, Daniela Behr and Clara Neupert-Wentz. 2018. "The Constitutionalization of Indigenous Group Rights, Traditional Political Institutions, and Customary Law." Comparative Political Studies 52, 12: 1775-1809.

Holzinger, Katharina, Florian G. Kern and Daniela Kromrey. 2016. "The Dualism of Contemporary Traditional Governance and the State: Institutional Setups and Political Consequences". Political Research Quarterly (69(3): 469-481.

Holzinger, Katharina, Florian G. Kern and Daniela Kromrey. 2017. Traditional Institutions in subSaharan Africa: Endangering or Promoting Stable Domestic Peace? Research Report No. 42. Osnabrück: Deutsche Stiftung Friedensforschung.

JuriGlobe World Legal Systems Research Group. 2019. Percentage of the World Population, Customary Law Systems. University of Ottawa. http://www.juriglobe.ca/eng/systdemo/graph.php_(last accessed September 30, 2019).

Keulder, Christiaan. 1997. Traditional Authorities and Regional Councils in Southern Namibia. Windhoek, Namibia: Friedrich Ebert-Stiftung.

Kirshner, Joshua and Marcus Power. 2015. "Mining and Extractive Urbanism: Postdevelopment in a Mozambican Boomtown." Geoforum 61, 67-78.

Koelble, Thomas A. and Edward LiPuma. 2011. "Traditional Leaders and the Culture of Governance in South Africa." Governance 24, 1: 5-29. 
Koter, Dominika. 2013. "King makers: local leaders and ethnic politics in Africa." World Politics 65, 2: $187-232$.

Krogslund, Chris, Donghyun Danny Choi, and Mathias Poertner, 2015. "Fuzzy Sets on Shaky Grounds? Parametric and Specification Sensitivity in fsQCA." Political Analysis 23(1): 21-41.

Lange, Matthew K. 2004. "British Colonial Legacies and Political Development." World Development 32, 6: 905-922.

Lechler, Marie and Lachlan McNamee. 2018. "Indirect Colonial Rule Undermines Support for Democracy: Evidence From a Natural Experiment in Namibia." Comparative Political Studies 51, 14: 1858-1898.

Logan, Carolyn. 2009. "Selected Chiefs, Elected Councillors and Hybrid Democrats. Popular Perspectives on the Co-existence of Democracy and Traditional Authority." The Journal of Modern African Studies 47, 1: 101-128.

Logan, Carolyn. 2013. "The Roots of Resilience: Exploring Popular Support for African Traditional Authorities." African Affairs 112, 448: 353-376.

Lucas, Samuel R., and Alisa Szatrowski. 2014. "Qualitative Comparative Analysis in Critical Perspective." Sociological Methodology 44, 1: 1-79.

Mamdani, Mahmood. 1996. Citizen and Subject. Contemporary Africa and the Legacy of Late Colonialism. Princeton, N.J.: Princeton University Press.

Mustasilta, Katariina. 2019. "Including chiefs, maintaining peace? Examining the effects of statetraditional governance interaction on civil peace in sub-Saharan Africa." Journal of Peace Research 56, 2: 203-219.

Medzihorsky, Juraj, Ioana-Elena Oana, Mario Quaranta and Carsten Q. Schneider. 2016. SetMethods: Functions for Set-Theoretic Multi-Method Research and Advanced QCA. R package version 2.0.

Mengisteab, Kidane and Gerard Hagg. 2017. Traditional Institutions in Contemporary African Governance, London/New York: Routledge.

Muriaas, Ragnhild L. 2009. "Local Perspectives on the 'Neutrality' of Traditional Authorities in Malawi, South Africa and Uganda." Commonwealth \& Comparative Politics 47, 1: 28-51.

Munck, Gerardo L. 2016. "Assessing Set-Theoretic Comparative Methods: A Tool for Qualitative Comparativists?" Comparative Political Studies 49, 6: 775-780.

Nabudere, Dan Wadada. 2004. "Traditional and Modern Political Systems in Contemporary Governance in Africa." Journal of African Elections 3, 1: 13-41.

Oomen, Barbara, and Ineke van Kessel. 1997. “'One Chief, One Vote': The Revival of Traditional Authorities in Post-Apartheid South Africa." African Affairs 96: 561-585 
Paine, Jack. 2016. "Set-Theoretic Comparative Methods Less Distinctive Than Claimed." Comparative Political Studies 49, 6: 703-41.

Ragin, Charles. 2000. Fuzzy-set Social Science, Chicago: University of Chicago Press.

Ragin, Charles. 2014. "Comment Lucas and Szatrowski in Critical Perspective." Sociological Methodology 44, 1: 80-94.

Ragin, Charles C, Drass KA and Davey S. 2006. Fuzzy-Set/Qualitative Comparative Analysis 2.0. Tucson, Arizona: Department of Sociology, University of Arizona.

Ragin, Charles, and Benoît Rihoux. 2004. "Replies to Commentators: Reassurances and Rebuttals." Qualitative Methods 2, 2: 22-24.

Rihoux, Benoît and Charles Ragin. 2009. Configurational Comparative Methods. Qualitative Comparative Analysis (QCA) and Related Techniques, Houndmills: Sage.

Rihoux, Benoît and Axel Marx (eds.) 2013. "QCA, 25 Years after 'The Comparative Methods': Mapping, Challenges and Innovations - Mini Symposium.” Political Research Quarterly 66, 1: 167235 .

Rohlfing, Ingo. 2015. "Mind the gap: A review of simulation designs for Qualitative Comparative Analysis", Research \& Politics 2, 4: 1-4.

Schneider, Carsten Q. and Ingo Rohlfing. 2016. "Case Studies Nested in Fuzzy-Set QCA on Sufficiency Formalizing Case Selection and Causal Inference.” Sociological Methods \& Research 45, 3: 526 568.

Schneider Carten Q. und Claudius Wagemann. .2007. Qualitative Comparative Analysis (QCA) und fuzzy sets: ein Lehrbuch für Anwender und jene, die es werden wollen. Leverkusen: Barbara Budrich.

Schneider, Carsten Q., and Claudius Wagemann. 2010. "Standards of Good Practice in Qualitative Comparative Analysis (QCA) and Fuzzy-Sets." Comparative Sociology 9(3): 397-418.

Schneider, Carsten Q., and Claudius Wagemann. 2012. Set-theoretic Methods for the Social Sciences: A Guide to Qualitative Comparative Analysis, Cambridge: Cambridge University Press.

Schulz, Nicolai. 2015. "Dangerous Demographics? The Effect of Urbanisation and Metropolisation on African Civil Wars, 1961-2010.” Civil Wars 17, 3: 291-317.

Sklar, Richard. 1999. "The Significance of Mixed Government in Southern African Studies." In Jonathan Hyslop, ed., African Democracy in the Era of Globalization. Johannesburg, South Africa: Witwatersrand University Press: 115-121.

Thiem, Alrik. 2014 "Navigating the Complexities of Qualitative Comparative Analysis: Case Numbers, Necessity Relations, and Model Ambiguities.” Evaluation Review 38, 6: 487-513. 
Thiem, Alrik. 2016. QCApro: Professional Functionality for Performing and Evaluating Qualitative Comparative Analysis. R Package Version 1.1-1.

Thiem, Alrik. 2017. "Standards of Good Practice and the Methodology of Necessary Conditions in Qualitative Comparative Analysis." Political Analysis 24, 4: 478-484.

Tsebelis, George and Dominic J. Nardi. 2014. “A long constitution is a (positively) bad constitution: Evidence from OECD countries." British Journal of Political Science 46(2): 457-478.

Tinker, Hugh. 1977. "Between Africa, Asia and Europe: Mauritius: Cultural Marginalism and Political Control." African Affairs 76: 321-338.

Ubink, Janine. 2008. Traditional Authorities in Africa. Resurgence in an Era of Democratisation. Leiden, Netherlands: Leiden University Press.

van der Windt, Peter, Macartan Humphreys, Lily Medina, Jeffrey F. Timmons, and Maarten Voors. 2019. "Citizen Attitudes Toward Traditional and State Authorities: Substitutes or Complements?" Comparative Political Studies 52, 12: 1810-1840.

Welz, Martin and Daniela Kromrey. 2015. "Legacies of the Past: The Influence of Former Freedom Fighters and their Rhetoric in Southern Africa." Politikon: South African Journal of Political Studies 42, 2: 255-273.

Wig, Tore and Daniela Kromrey. 2018. "Which groups fight? Customary institutions and communal conflicts in Africa." Journal of Peace Research: 55, 4 : 415-429.

Young, Crawford. 1994. The African Colonial State in Comparative Perspective. Yale University Press. 


\section{Tables}

\section{Table 1 Calibration of constitutional integration}

\begin{tabular}{lll}
\hline Value & Outcome & Attribution \\
\hline 1.0 & Integration & TPI are part of the state and institutionalized but subordinated to the state \\
0.7 & Dualism & $\begin{array}{l}\text { TPI are recognized and accepted by the state; customary law exists next to state } \\
\text { law; TPI are granted semi-autonomous rights in specific fields (e.g. dispute set- } \\
\text { tlement, cultural rituals, land rights) }\end{array}$ \\
& $\begin{array}{l}\text { TPI are not officially recognized but tolerated, e.g. indigenous languages are sup- } \\
\text { ported. State law is the only officially recognized law }\end{array}$ \\
0.3 & Tolerance & The constitution does not recognize or tolerate TPI
\end{tabular}

Table 2 Extent of constitutional integration, 1990 and current constitutions

\begin{tabular}{llcccc}
\hline Value & Outcome & \multicolumn{2}{c}{ Number of countries } & \multicolumn{2}{c}{ Percentage } \\
\hline & & 1990 & current & 1990 & current \\
\hline 1.0 & Integration & 12 & 15 & 26.6 & 33.3 \\
0.7 & Dualism & 3 & 13 & 6.7 & 28.9 \\
0.3 & Tolerance & 7 & 5 & 15.6 & 11.1 \\
0.0 & Non-integration & 23 & 12 & 51.1 & 26.7 \\
\hline & & 45 & 45 & 100.0 & 100.0 \\
\hline
\end{tabular}

Table 3 Description of constitutional resurgence

\begin{tabular}{llcc}
\hline Value & Outcome & Number of countries & Percentage \\
\hline 1.0 & Resurgence & 16 & 35.6 \\
0.5 & No change & 23 & 51.1 \\
0.0 & Dismantling & 6 & 13.3 \\
\hline & & 45 & 100.0 \\
\hline
\end{tabular}


Table 4 Parsimonious solution for integration ${ }^{\mathrm{a}}$

\begin{tabular}{llll}
\hline $\begin{array}{l}\text { frequency cutoff: } 1.000000 \\
\text { consistency cutoff: } 0.746024\end{array}$ & raw coverage & unique coverage & consistency \\
\hline colonial* metro & 0.488083 & 0.488083 & 0.827099 \\
\hline Solution coverage: & 0.488083 & & \\
solution consistency: $\quad 0.827099$ & & \\
\hline a may contain problematic counterfactuals & & \\
\hline
\end{tabular}

\section{Table 5 Parsimonious solution for resurgence (model 1, three conditions) ${ }^{\mathrm{a}}$}

\begin{tabular}{llll}
$\begin{array}{l}\text { frequency cutoff: } 1.000000 \\
\text { consistency cutoff: } 0.842648\end{array}$ & raw coverage & unique coverage & consistency \\
\hline$\sim$ metro & 0.778849 & 0.385180 & 0.795044 \\
$\sim$ demo & 0.422783 & 0.029114 & 0.836097 \\
\hline & & & \\
solution coverage: & 0.807963 & & \\
solution consistency: & 0.783290 & & \\
\hline
\end{tabular}

Table 6 Parsimonious solution for resurgence (model 2, four conditions) ${ }^{\text {a }}$

\begin{tabular}{llll}
\hline $\begin{array}{l}\text { frequency cutoff: } 1.000000 \\
\text { consistency cutoff: } 0.893158\end{array}$ & raw coverage & unique coverage & consistency \\
\hline $\begin{array}{l}\sim \text { metro* oda } \\
\sim \text { demo }\end{array}$ & 0.656263 & 0.285522 & 0.890278 \\
\hline & 0.422783 & 0.052042 & 0.836097 \\
$\begin{array}{l}\text { Solution coverage: } \\
\text { Solution consistency: }\end{array}$ & 0.708305 & & \\
\hline \\
a $\quad 0.83496$ & & \\
\hline
\end{tabular}




\section{Annex - QCA analyses, robustness checks; alternative approaches}

\section{Analysis of integration}

\section{Truth table}

Table A1 Truth table for constitutional integration

\begin{tabular}{|c|c|c|c|c|c|c|c|c|c|c|}
\hline $\begin{array}{l}\text { Colonial } \\
\text { rule }\end{array}$ & Democracy & $\begin{array}{c}\text { State } \\
\text { capacity }\end{array}$ & Metropolization & Development & $\begin{array}{l}\text { Number } \\
\text { of cases }\end{array}$ & Integration & $\begin{array}{c}\text { Raw } \\
\text { consistency }\end{array}$ & PRI consistency & Product & Countries \\
\hline 0 & 0 & 0 & 0 & 0 & 12 & & 0.621354 & 0.431481 & 0.268102 & $\begin{array}{l}\text { Benin, Burkina Faso, Cameroon, CAR, Chad, } \\
\text { Cote d'Ivoire, Eq. Guinea, Guinea, } \\
\text { Madagascar, Mali, Niger, Rwanda }\end{array}$ \\
\hline 1 & 1 & 0 & 0 & 0 & 6 & & 0.920901 & 0.903637 & 0.832160 & $\begin{array}{l}\text { Kenya, Lesotho, Malawi, Sierra Leone, } \\
\text { Zambia, Zimbabwe }\end{array}$ \\
\hline 1 & 0 & 0 & 0 & 0 & 5 & & 0.868147 & 0.833855 & 0.723909 & Ghana, Nigeria, Sudan, Tanzania, Uganda \\
\hline 0 & 1 & 0 & 0 & 0 & 4 & & 0.587478 & 0.366313 & 0.215201 & Comoros, DRC, Ethiopia, Mozambique \\
\hline 0 & 1 & 0 & 1 & 0 & 4 & & 0.479710 & 0.189848 & 0.091072 & Burundi, Djibouti, Guinea-Bissau, Senegal \\
\hline 1 & 1 & 1 & 0 & 1 & 4 & & 0.746024 & 0.731199 & 0.545492 & Botswana, Mauritius, Namibia, South Africa \\
\hline 0 & 0 & 0 & 1 & 0 & 2 & & 0.559589 & 0.295709 & 0.165475 & Mauretania, Togo \\
\hline 1 & 0 & 0 & 1 & 0 & 2 & & 0.680323 & 0.589642 & 0.401147 & Eritrea, Gambia \\
\hline 0 & 0 & 0 & 0 & 1 & 2 & & 0.660537 & 0.48691 & 0.321622 & Angola, Gabon \\
\hline 1 & 0 & 0 & 0 & 1 & 1 & & 1.000000 & 1.000000 & 1.000000 & Swaziland \\
\hline 0 & 0 & 0 & 1 & 1 & 1 & & 0.509935 & 0.221262 & 0.112829 & Congo \\
\hline 0 & 0 & 1 & 0 & 0 & 0 & log remain & & & & \\
\hline 1 & 0 & 1 & 0 & 0 & 0 & log remain & & & & \\
\hline 0 & 0 & 1 & 1 & 0 & 0 & log remain & & & & \\
\hline 1 & 0 & 1 & 1 & 0 & 0 & log remain & & & & \\
\hline 1 & 0 & 0 & 1 & 1 & 0 & $\log$ remain & & & & \\
\hline 0 & 0 & 1 & 0 & 1 & 0 & log remain & & & & \\
\hline 1 & 0 & 1 & 0 & 1 & 0 & $\log$ remain & & & & \\
\hline
\end{tabular}




\begin{tabular}{lllllll}
0 & 0 & 1 & 1 & 1 & 0 & $\log$ remain \\
1 & 0 & 1 & 1 & 1 & 0 & $\log$ remain \\
1 & 1 & 0 & 1 & 0 & 0 & $\log$ remain \\
0 & 1 & 1 & 0 & 0 & 0 & $\log$ remain \\
1 & 1 & 1 & 0 & 0 & 0 & $\log$ remain \\
0 & 1 & 1 & 1 & 0 & 0 & $\log$ remain \\
1 & 1 & 1 & 1 & 0 & 0 & $\log$ remain \\
0 & 1 & 0 & 0 & 1 & 0 & $\log$ remain \\
1 & 1 & 0 & 0 & 1 & 0 & $\log$ remain \\
0 & 1 & 0 & 1 & 1 & 0 & $\log$ remain \\
1 & 1 & 0 & 1 & 1 & 0 & $\log$ remain \\
0 & 1 & 1 & 0 & 1 & 0 & $\log$ remain \\
0 & 1 & 1 & 1 & 1 & 0 & $\log$ remain \\
1 & 1 & 1 & 1 & 1 & 0 & $\log$ remain \\
\hline
\end{tabular}




\section{Necessary conditions, integration}

Table A2.1 Analysis of necessary conditions for integration and non-integration

\begin{tabular}{lc|c|cc}
\hline & \multicolumn{2}{c|}{ Integration } & \multicolumn{2}{c}{ Non-integration } \\
\hline Condition & Consistency & Coverage & Consistency & Coverage \\
\hline Colonial rule & 0.577406 & 0.766667 & 0.219895 & 0.233333 \\
$\sim$ Colonial rule & 0.422594 & 0.404000 & 0.780105 & 0.596000 \\
Democracy & 0.633975 & 0.668684 & 0.616115 & 0.519333 \\
$\sim$ Democracy & 0.544283 & 0.639528 & 0.606941 & 0.569924 \\
State capacity & 0.422071 & 0.725067 & 0.412042 & 0.565678 \\
$\sim$ State capacity & 0.747176 & 0.613924 & 0.799738 & 0.525140 \\
Metropolization & 0.290098 & 0.539547 & 0.487767 & 0.724992 \\
$\sim$ Metropolization & 0.852136 & 0.675498 & 0.690212 & 0.437253 \\
Economic development & 0.244521 & 0.671537 & 0.190260 & 0.417577 \\
$\sim$ Economic development & 0.787927 & 0.549062 & 0.850343 & 0.473549 \\
\hline The “ “ represents the negation or the absence of the causal condition. & &
\end{tabular}

Table A2.2 Compound analysis of necessary conditions for integration and nonintegration

\begin{tabular}{|c|c|c|c|c|}
\hline \multirow[b]{2}{*}{ Condition } & \multicolumn{2}{|c|}{ Integration } & \multicolumn{2}{|c|}{ Non-integration } \\
\hline & Consistency & Coverage & Consistency & Coverage \\
\hline$\sim$ Metropolization $+\sim$ Colonial rule & 0.910677 & 0.556601 & . & . \\
\hline$\sim$ Metropolization + Colonial rule & 0.941459 & 0.660896 & . & . \\
\hline$\sim$ State Capacity + Colonial rule & 0.949895 & 0.624896 & . & . \\
\hline State Capacity $+\sim$ Colonial rule & . & · & 0.905628 & 0.536481 \\
\hline$\sim$ Economic development + Colonial rule & 0.948611 & 0.576514 & & \\
\hline$\sim$ Economic development $+\sim$ Metropolization & 0.960785 & 0.576969 & . & . \\
\hline Democracy $+\sim$ Economic development & 0.918756 & 0.570006 & . & . \\
\hline$\sim$ Democracy $+\sim$ Colonial rule & . & . & 0.907785 & 0.539433 \\
\hline $\begin{array}{l}\sim \text { Economic development }+ \text { State Capacity }+ \\
\sim \text { Colonial rule }\end{array}$ & 0.928714 & 0.541723 & . & . \\
\hline $\begin{array}{l}\text { Economic development }+\sim \text { State Capacity }+ \\
\sim \text { Metropolization }\end{array}$ & 0.908014 & 0.603088 & . & . \\
\hline$\sim$ Democracy $+\sim$ State Capacity $+\sim$ Metropolization & 0.909099 & 0.604031 & . & . \\
\hline $\begin{array}{l}\text { Economic development }+ \text { Metropolization } \\
+\sim \text { Colonial rule }\end{array}$ & . & . & 0.925865 & 0.533438 \\
\hline
\end{tabular}


$\sim$ Democracy $+\sim$ Economic development + State Capacity

$\sim$ Democracy + Economic development + $\sim$ Metropolization

Democracy $+\sim$ State Capacity $+\sim$ Colonial rule

Democracy $+\sim$ State Capacity $+\sim$ Metropolization

Democracy + Economic Development + $\sim$ Metropolization

$\sim$ Democracy + State Capacity + Metropolization + Colonial rule

$\sim$ Democracy $+\sim$ Economic Development $+\sim$ State Capacity $+\sim$ Colonial rule

$\sim$ Democracy + Economic Development + Metropolization + Colonial rule

$\sim$ Democracy + Economic Development $+\sim$ State Capacyity $+\sim$ Colonial rule
$0.932013 \quad 0.563371$

$0.909417 \quad 0.636788$

$0.911623 \quad 0.551064$

$0.921561 \quad 0.604233$

$0.900377 \quad 0.632679$

$0.904239 \quad 0.646951$

$0.901548 \quad 0.544196$

$0.901455 \quad 0.641210$

$0.905650 \quad 0.550880$

The " " represents the negation or the absence of the causal condition. Solution terms are only reported if they have a consistency level higher 0.90 . 


\section{Sufficient conditions, integration}

Table A3 Complex solution for integration ${ }^{\mathrm{a}}$

\begin{tabular}{|c|c|c|c|c|}
\hline \multicolumn{2}{|c|}{$\begin{array}{l}\text { frequency cutoff: } 1.000000 \\
\text { consistency cutoff: } 0.746024\end{array}$} & raw coverage & unique coverage & consistency \\
\hline \multicolumn{2}{|c|}{ colonial $^{*} \sim$ metro $^{*} \sim$ statcap $^{*} \sim$ gdp } & 0.309659 & 0.129132 & 0.898760 \\
\hline \multicolumn{2}{|c|}{ colonial $^{*} \sim$ metro $^{*} \sim$ statcap $^{*} \sim$ demo } & 0.205881 & 0.017708 & 0.883299 \\
\hline \multicolumn{2}{|c|}{ colonial $* \sim$ metro*statcap $*$ gdp $*$ demo } & 0.106311 & 0.080322 & 0.746024 \\
\hline $\begin{array}{l}\text { solution coverage: } \\
\text { solution consistency: }\end{array}$ & $\begin{array}{l}0.416766 \\
0.854310\end{array}$ & & & \\
\hline no counterfactu & ogical remaind & & & \\
\hline
\end{tabular}

\section{Sufficient conditions, non-integration}

Table A4 Complex solution for non-integration ${ }^{\mathrm{a}}$

\begin{tabular}{|c|c|c|c|c|}
\hline \multicolumn{2}{|c|}{$\begin{array}{l}\text { frequency cutoff: } 1.000000 \\
\text { consistency cutoff: } 0.815086\end{array}$} & raw coverage & unique coverage & consistency \\
\hline \multicolumn{2}{|c|}{$\sim$ colonial $^{*}$ metro $* \sim$ statcap $* \sim$ demo } & 0.299706 & 0.030992 & 0.825724 \\
\hline \multicolumn{2}{|c|}{$\sim$ colonial $^{*}$ metro $* \sim$ statcap $^{*} \sim$ gdp } & 0.350024 & 0.081310 & 0.831445 \\
\hline $\begin{array}{l}\text { solution coverage: } \\
\text { solution consistency: }\end{array}$ & $\begin{array}{l}0.381016 \\
0.838746\end{array}$ & & & \\
\hline no counterfactu & logical remair & & & \\
\hline
\end{tabular}

Table A5 Parsimonious solution for non-integration ${ }^{\mathrm{a}}$

\begin{tabular}{|lllll|}
\hline $\begin{array}{l}\text { frequency cutoff: } 1.000000 \\
\text { consistency cutoff: } 0.815086\end{array}$ & raw coverage & unique coverage & consistency \\
\hline colonial*metro & & 0.395545 & 0.395545 & 0.843743 \\
\hline solution coverage: $\quad 0.395545$ & & \\
solution consistency: $\quad 0.843743$ & & \\
\hline a $\quad$ includes all logical remainders & & \\
\hline
\end{tabular}




\section{Robustness-check: excluding the condition state capacity}

\section{Sufficient conditions}

Table A6 Complex and parsimonious solution for integration ${ }^{\mathrm{a}}$

\begin{tabular}{|llcc|}
\hline $\begin{array}{l}\text { frequency cutoff: } 1.000000 \\
\text { consistency cutoff: } 0.760103\end{array}$ & raw coverage & unique coverage & consistency \\
\hline metro*colonial & 0.488083 & 0.488083 & 0.827099 \\
\hline & & & \\
solution coverage: & 0.488083 & & \\
solution consistency: & 0.827099 & & \\
\hline a $\quad$ in the complex solution no counterfactuals/ logical remainders included, the parsimonious solution contains all logical \\
\hline
\end{tabular}

\section{Robustness-check: crisp-set analysis (csQCA)}

\section{Necessary conditions}

Table A7 Analysis of necessary conditions for integration and non-integration

\begin{tabular}{lcc|c|c}
\hline & \multicolumn{2}{c}{ Integration } & \multicolumn{2}{c}{ Non-integration } \\
\hline Condition & Consistency & Coverage & Consistency & Coverage \\
\hline Colonial rule & 0.576923 & 0.833333 & 0.176471 & 0.166667 \\
$\sim$ Colonial rule & 0.423077 & 0.440000 & 0.823529 & 0.560000 \\
Democracy & 0.461538 & 0.666667 & 0.352941 & 0.333333 \\
$\sim$ Democracy & 0.538462 & 0.560000 & 0.647059 & 0.440000 \\
State capacity & 0.115385 & 0.750000 & 0.058824 & 0.250000 \\
$\sim$ State capacity & 0.884615 & 0.589744 & 0.941176 & 0.410256 \\
Metropolization & 0.076923 & 0.222222 & 0.411765 & 0.777778 \\
$\sim$ Metropolization & 0.923077 & 0.705882 & 0.588235 & 0.294118 \\
Economic development & 0.192308 & 0.625000 & 0.176471 & 0.375000 \\
$\sim$ Economic development & 0.807692 & 0.600000 & 0.823529 & 0.400000 \\
\hline The “ “ represents the negation or the absence of the causal condition. & & &
\end{tabular}




\section{Sufficient conditions, integration}

Table A8 Complex solution for integration ${ }^{\mathrm{a}}$

\begin{tabular}{|c|c|c|c|c|}
\hline \multicolumn{2}{|c|}{$\begin{array}{l}\text { frequency cutoff: } 1.000000 \\
\text { consistency cutoff: } 0.750000\end{array}$} & raw coverage & unique coverage & consistency \\
\hline \multicolumn{2}{|c|}{ metro* $\sim$ statcap $* \sim$ gdp*demo } & 0.346154 & 0.346154 & 0.900000 \\
\hline \multicolumn{2}{|c|}{ colonial $^{*} \sim$ metro $^{*} \sim$ statcap $^{*} \sim$ demo } & 0.192308 & 0.192308 & 0.833333 \\
\hline \multicolumn{2}{|c|}{ colonial $^{*} \sim$ metro* ${ }^{*}$ statcap*gdp*demo } & 0.115385 & 0.115385 & 0.750000 \\
\hline $\begin{array}{l}\text { solution coverage: } \\
\text { solution consistency: }\end{array}$ & $\begin{array}{l}0.653846 \\
0.850000\end{array}$ & & & \\
\hline \multicolumn{5}{|c|}{ a no counterfactuals / logical remainders included } \\
\hline
\end{tabular}

Table A9 Parsimonious solution for integration ${ }^{\mathrm{a}}$

\begin{tabular}{|c|c|c|c|c|}
\hline \multicolumn{2}{|c|}{$\begin{array}{l}\text { frequency cutoff: } 1.000000 \\
\text { consistency cutoff: } 0.746024\end{array}$} & \multirow{2}{*}{$\begin{array}{l}\text { raw coverage } \\
0.538462\end{array}$} & \multirow{2}{*}{$\begin{array}{l}\text { unique coverage } \\
0.192308\end{array}$} & \multirow{2}{*}{$\begin{array}{l}\text { consistency } \\
0.875000\end{array}$} \\
\hline colonial $* \sim$ metro & & & & \\
\hline demo $* \sim$ metro & & 0.461538 & 0.115385 & 0.857143 \\
\hline $\begin{array}{l}\text { solution coverage: } \\
\text { solution consistency: }\end{array}$ & $\begin{array}{l}0.653846 \\
0.850000\end{array}$ & & & \\
\hline
\end{tabular}


Additional statistical analyses, integration

\section{Correlations}

Table A10 Correlation matrix

\begin{tabular}{|c|c|c|c|c|c|c|}
\hline & Integration & $\begin{array}{c}\text { Colonial } \\
\text { Rule }\end{array}$ & Democracy & $\begin{array}{c}\text { State } \\
\text { capacity }\end{array}$ & $\begin{array}{c}\text { Metro- } \\
\text { polization }\end{array}$ & $\begin{array}{c}\text { Economic } \\
\text { Develop. }\end{array}$ \\
\hline Integration & 1.00 & & & & & \\
\hline Colonial rule & $0.44 *$ & 1.00 & & & & \\
\hline Democracy & 0.08 & 0.22 & 1.00 & & & \\
\hline State capacity & 0.23 & 0.35 & 0.29 & 1.00 & & \\
\hline Metropolization & $-0.42 *$ & -0.30 & -0.20 & -0.25 & 1.00 & \\
\hline $\begin{array}{l}\text { Economic } \\
\text { development }\end{array}$ & 0.08 & 0.22 & 0.23 & $0.60 *$ & -0.20 & 1.00 \\
\hline
\end{tabular}

\section{Regressions}

Table A11 Ordered Logit Regression analysis of integration

\begin{tabular}{lcc}
\hline Variables & \multicolumn{1}{c}{ Ordered Logit-Models } \\
\hline Colonial rule & $1.64 * *$ & 0.72 \\
& $(0.69)$ & $(2.01)$ \\
Democracy & -0.02 & $(0.06)$ \\
& $(0.06)$ & 0.46 \\
State capacity & 0.47 & $(0.62)$ \\
& $(0.62)$ & $-0.06 *$ \\
Metropolization & $-0.05^{* *}$ & $(0.03)$ \\
Economic development & $(0.02)$ & 0.001 \\
Colonial rule*Metropolization & -0.001 & $(0.001)$ \\
Constant & $(0.001)$ & 0.024 \\
\hline N & & $(0.05)$ \\
$\mathrm{R}^{2} /$ Pseudo R & & \\
Log likelihood & & 43 \\
\hline Standard deviation in brackets* $p<.10 * * p<.05, * * * p<.01$ & 43 & 0.1445 \\
\hline
\end{tabular}




\section{Analysis of Resurgence}

\section{Necessary conditions}

Table A12.1 Analysis of necessary conditions for resurgence and non-resurgence

\begin{tabular}{lc|c|c|c}
\hline & \multicolumn{2}{c}{ Resurgence } & \multicolumn{2}{c}{ Non-resurgence } \\
\hline Condition & Consistency & Coverage & Consistency & Coverage \\
\hline Democratization & 0.875139 & 0.665645 & 0.898975 & 0.560960 \\
$\sim$ Democratization & 0.422783 & 0.836097 & 0.464174 & 0.753075 \\
Metropolization, increase & 0.652673 & 0.776293 & 0.755261 & 0.736962 \\
$\sim$ Metropolization, increase & 0.778849 & 0.795044 & 0.770738 & 0.645451 \\
$\begin{array}{l}\text { Economic development, } \\
\text { increase }\end{array}$ & 0.757383 & 0.805621 & 0.808903 & 0.705879 \\
$\begin{array}{l}\sim \text { Economic development, } \\
\text { increase }\end{array}$ & 0.723490 & & 0.777251 & 0.724381 \\
The “ “ represents the negation or the absence of the causal condition. & & & \\
\hline
\end{tabular}

Table A12.2 Compound analysis of necessary conditions for resurgence and nonresurgence

\begin{tabular}{|c|c|c|c|c|}
\hline \multirow[b]{2}{*}{ Condition } & \multicolumn{2}{|c|}{ Resurgence } & \multicolumn{2}{|c|}{ Non-resurgence } \\
\hline & Consistency & Coverage & Consistency & Coverage \\
\hline Democracy + Metropolization & . & . & 0.926711 & 0.556319 \\
\hline Democracy $+\sim$ Metropolization & 0.909556 & 0.647099 & 0.933041 & 0.544578 \\
\hline Democracy + Economic Development & 0.923193 & 0.6501225 & 0.947404 & 0.547339 \\
\hline Democracy $+\sim$ Economic Development & 0.919370 & 0.6680986 & 0.943019 & 0.562197 \\
\hline
\end{tabular}




\section{Analysis of resurgence}

\section{Truth table. Model 1}

Table A13 Truth table for constitutional resurgence

\begin{tabular}{|c|c|c|c|c|c|c|c|c|}
\hline Democracy & Metropolization & Development & $\begin{array}{l}\text { Number } \\
\text { of cases }\end{array}$ & Resurgence & $\begin{array}{l}\text { Raw } \\
\text { consistency }\end{array}$ & $\begin{array}{c}\text { PRI } \\
\text { consistency }\end{array}$ & Product & Countries \\
\hline 1 & 0 & 1 & 11 & & 0.865319 & 0.616085 & 0.53311 & $\begin{array}{l}\text { Angola, Botswana, Chad, Equatorial Guinea, Ghana, Guinea, } \\
\text { Lesotho, Mauritania, Mozambique, Rwanda, Uganda }\end{array}$ \\
\hline 1 & 1 & 1 & 10 & & 0.844734 & 0.6536277 & 0.453011 & $\begin{array}{l}\text { Burkina Faso, Guinea-Bissau, Kenya, Malawi, Namibia, Nigeria, } \\
\text { South Africa, Sudan, Swaziland, Zambia }\end{array}$ \\
\hline 1 & 1 & 0 & 9 & & 0.821223 & 0.495480 & 0.406900 & $\begin{array}{l}\text { Cameroon, Comoros, Djibouti, DRC, Mali, Niger, Senegal, Sierra } \\
\text { Leone, Togo }\end{array}$ \\
\hline 1 & 0 & 0 & 9 & & 0.869588 & 0.495480 & 0.406900 & $\begin{array}{l}\text { Burundi, CAR, Congo, Cote d'Ivoire, Ethiopia, Gabon, Madagascar, } \\
\text { Tanzania, Zimbabwe }\end{array}$ \\
\hline 0 & 0 & 1 & 1 & & 0.904647 & 0.647814 & 0.586043 & Gambia \\
\hline 0 & 1 & 1 & 1 & & 0.882317 & 0.603468 & 0.532450 & Eritrea \\
\hline 0 & 0 & 0 & 0 & log remain & & & & \\
\hline 0 & 1 & 0 & 0 & log remain & & & & \\
\hline
\end{tabular}




\section{Sufficient conditions, resurgence}

Table A14 Complex solution Resurgence ${ }^{\mathrm{a}}$

\begin{tabular}{|llll|}
\hline $\begin{array}{l}\text { frequency cutoff: } 1.000000 \\
\text { consistency cutoff: } 0.865319\end{array}$ & raw coverage & unique coverage & consistency \\
\hline $\begin{array}{l}\sim \text { metro*demo } \\
\sim \text { demo*econ }\end{array}$ & 0.744431 & 0.403952 & 0.837604 \\
\hline & 0.397540 & 0.057061 & 0.894785 \\
Solution coverage: & 0.801493 & & \\
solution consistency: & 0.840036 & & \\
\hline a & & \\
\hline \multicolumn{2}{|c|}{ no counterfactuals/logical remainders are included } \\
\hline
\end{tabular}

\section{Sufficient conditions, non-resurgence}

Table A15 Complex solution non-resurgence ${ }^{\mathrm{a}}$

\begin{tabular}{|c|c|c|c|c|}
\hline \multicolumn{2}{|c|}{$\begin{array}{l}\text { frequency cutoff: } 1.000000 \\
\text { consistency cutoff: } 0.805536\end{array}$} & \multirow{2}{*}{$\frac{\text { raw coverage }}{0.443275}$} & \multirow{2}{*}{$\begin{array}{l}\text { unique coverage } \\
0.074971\end{array}$} & \multirow{2}{*}{$\begin{array}{l}\text { consistency } \\
0.818520\end{array}$} \\
\hline$\sim$ demo*econ & & & & \\
\hline demo*metro & & 0.727524 & 0.359220 & 0.756572 \\
\hline $\begin{array}{l}\text { solution coverage: } \\
\text { solution consistency: }\end{array}$ & $\begin{array}{l}0.802495 \\
0.765121\end{array}$ & & & \\
\hline no counterfactu & ogical remainders included & & & \\
\hline
\end{tabular}

Table A16 Parsimonious solution non-resurgence ${ }^{\mathrm{a}}$

\begin{tabular}{|llll|}
\hline $\begin{array}{l}\text { frequency cutoff: } 1.000000 \\
\text { consistency cutoff: } 0.805536\end{array}$ & raw coverage & unique coverage & consistency \\
\hline metro & 0.755260 & 0.359894 & 0.736962 \\
$\sim$ demo & 0.464174 & 0.068808 & 0.753075 \\
\hline & & & \\
Solution coverage: & 0.824068 & & \\
solution consistency: & 0.725674 & & \\
\hline a & & & \\
\hline
\end{tabular}


Robustness-check: excluding cases without constitutional change $(\mathrm{N}=21)$

Table A17 Analysis of necessary conditions for resurgence and non-resurgence

\begin{tabular}{|c|c|c|c|c|}
\hline \multirow[b]{2}{*}{ Condition } & \multicolumn{2}{|c|}{ Resurgence } & \multicolumn{2}{|c|}{ Non-resurgence } \\
\hline & Consistency & Coverage & Consistency & Coverage \\
\hline Democratization & 0.843770 & 0.695600 & 0.881878 & 0.487373 \\
\hline$\sim$ Democratization & 0.378178 & 0.826864 & 0.449203 & 0.658413 \\
\hline Metropolization, increase & 0.496954 & 0.673200 & 0.650781 & 0.590992 \\
\hline$\sim$ Metropolization, increase & 0.698072 & 0.748860 & 0.640138 & 0.460354 \\
\hline $\begin{array}{l}\text { Economic development, } \\
\text { increase }\end{array}$ & 0.604200 & 0.750046 & 0.644585 & 0.536421 \\
\hline $\begin{array}{l}\text { Economic development, } \\
\text { increase }\end{array}$ & 0.626564 & 0.724498 & 0.699645 & 0.542335 \\
\hline
\end{tabular}

Table A18 Complex solution resurgence ${ }^{\mathrm{a}}$

\begin{tabular}{|lllll|}
\hline $\begin{array}{l}\text { frequency cutoff: } 1.000000 \\
\text { consistency cutoff: } 0.751379\end{array}$ & raw coverage & unique coverage & consistency \\
\hline metro*demo & 0.686197 & 0.686197 & 0.771169 \\
\hline & & & \\
solution coverage: & 0.686197 & & \\
solution consistency: & 0.771169 & & \\
\hline a $\quad$ no counterfactuals / logical remainders included & & \\
\hline
\end{tabular}

Table A19 Parsimonious solution resurgence ${ }^{\mathrm{a}}$

\begin{tabular}{|lllll|}
\hline $\begin{array}{l}\text { frequency cutoff: } 1.000000 \\
\text { consistency cutoff: } 0.842648\end{array}$ & raw coverage & unique coverage & consistency \\
\hline metro & 0.698071 & 0.698071 & 0.748860 \\
\hline & & & \\
solution coverage: & 0.698071 & & \\
solution consistency: & 0.748860 & & \\
\hline a $\quad$ all counterfactuals / logical remainders included & & \\
\hline
\end{tabular}




\section{Robustness-check: crisp-set analysis (csQCA)}

Table A20 Analysis of necessary conditions for resurgence and non-resurgence

\begin{tabular}{lc|c|c|c}
\hline & \multicolumn{2}{c}{ Resurgence } & \multicolumn{2}{c}{ Non-resurgence } \\
\hline Condition & Consistency & Coverage & Consistency & Coverage \\
\hline Democratization & 0.960784 & 0.620253 & 0.939394 & 0.392405 \\
$\sim$ Democratization & 0.058824 & 0.600000 & 0.090909 & 0.600000 \\
Metropolization, increase & 0.431373 & 0.550000 & 0.545455 & 0.450000 \\
$\sim$ Metropolization, increase & 0.568627 & 0.659091 & 0.454545 & 0.340909 \\
$\begin{array}{l}\text { Economic development, } \\
\text { increase }\end{array}$ & 0.588235 & 0.625000 & 0.545455 & 0.375000 \\
$\begin{array}{l}\sim \text { Economic development, } \\
\text { increase }\end{array}$ & 0.411765 & 0.583333 & .454545 & 0.416667 \\
The “ “ represents the negation or the absence of the causal condition. & & \\
\hline
\end{tabular}

Table A21 Complex and parsimonious solution resurgence ${ }^{\mathrm{a}}$

\begin{tabular}{|lccc|}
\hline $\begin{array}{l}\text { frequency cutoff: } 1.000000 \\
\text { consistency cutoff: } 0.695652\end{array}$ & raw coverage & unique coverage & consistency \\
\hline $\begin{array}{l}\text { metro*demo*econ } \\
\text { melution coverage: }\end{array}$ & 0.313726 & 0.313726 & 0.695652 \\
\hline $\begin{array}{l}\text { solution consistency: } \\
\text { solution }\end{array}$ & 0.695652 & & \\
\hline $\begin{array}{l}\text { a no counterfactuals / logical remainders included in the complex solution, the parsimonious solution contains all logical } \\
\text { remainders; both solutions are identical }\end{array}$ \\
\hline
\end{tabular}

\section{Robustness-check: excluding the condition democratization}

Table A22 Model 1: Complex and parsimonious solution resurgence ${ }^{\mathrm{a}}$

\begin{tabular}{|llcc|}
\hline $\begin{array}{l}\text { frequency cutoff: } 1.000000 \\
\text { consistency cutoff: } 0.859328\end{array}$ & raw coverage & unique coverage & consistency \\
\hline metro & 0.778849 & 0.778849 & 0.795044 \\
\hline & & & \\
solution coverage: & 0.778849 & & \\
solution consistency: & 0.795044 & & \\
\hline $\begin{array}{l}\text { a no counterfactuals / logical remainders included in the complex solution, the parsimonious solution contains all logical } \\
\text { remainders; both solutions are identical }\end{array}$ \\
\hline
\end{tabular}




\section{Analysis of resurgence}

\section{Correlations}

Table A23 Correlation matrix

\begin{tabular}{|c|c|c|c|c|}
\hline & Resurgence & Democracy & Metropolization & Development \\
\hline Resurgence & 1.00 & & & \\
\hline Democratization & 0.08 & 1.00 & & \\
\hline Metropolization & -0.15 & 0.07 & 1.00 & \\
\hline Development & -0.09 & -0.24 & 0.06 & 1.00 \\
\hline
\end{tabular}

$* p<.1$

\section{Regressions}

Table A24 Regression analysis of resurgence, OLS

\begin{tabular}{lccc}
\hline Variables & Full Model & $\begin{array}{c}\text { OLS-Models } \\
\text { Without } \\
\text { Democratization }\end{array}$ & Reduced Sample \\
\hline Democratization & 0.004 & & 0.04 \\
Metropolization & $(0.009)$ & -0.01 & $(0.03)$ \\
Development & -0.013 & $(0.013)$ & -0.01 \\
Constant & $(0.013)$ & -0.001 & $0.2)$ \\
& -0.001 & $(0.001)$ & $(0.001)$ \\
$\mathrm{N}$ & $(0.001)$ & $0.01 *$ & 0.009 \\
$\mathrm{R}^{2}$ & 0.01 & $(0.005)$ & $(0.02)$ \\
\hline Stand & $(0.07)$ & 42 & 21 \\
\hline
\end{tabular}

Standard deviation in brackets; $* p<.1$ 
Additional robustness checks

Robustness-check: urbanization instead of metropolization, outcome integration

\section{Necessary conditions}

Table A25 Analysis of necessary conditions for integration and non-integration

\begin{tabular}{lccccc}
\hline & \multicolumn{2}{c|}{ Integration } & \multicolumn{2}{c}{ Non-integration } \\
\hline Condition & Consistency & Coverage & Consistency & Coverage \\
\hline Metropolization & 0.290098 & 0.539547 & 0.487767 & 0.724992 \\
$\sim$ Metropolization & 0.852136 & 0.675498 & 0.690212 & 0.437253 \\
Urbanization & 0.249420 & 0.579933 & 0.320074 & 0.594747 \\
$\sim$ Urbanization & 0.825707 & 0.603111 & 0.773933 & 0.451763 \\
\hline
\end{tabular}

The " " represents the negation or the absence of the causal condition.

\section{Sufficient conditions, integration}

Table A26 Complex solution for integration ${ }^{\mathrm{a}}$

\begin{tabular}{|c|c|c|c|c|}
\hline \multicolumn{2}{|c|}{$\begin{array}{l}\text { frequency cutoff: } 1.000000 \\
\text { consistency cutoff: } 0.706399\end{array}$} & raw coverage & unique coverage & consistency \\
\hline \multicolumn{2}{|c|}{ colonial $* \sim$ gdp $* \sim$ statcap $*$ urban } & 0.316521 & 0.285413 & 0.819385 \\
\hline \multicolumn{2}{|c|}{$\sim$ urban* $\sim$ statcap* $\sim$ demo*gdp } & 0.112151 & 0.073396 & 0.823053 \\
\hline \multicolumn{2}{|c|}{ colonial*statcap*gdp*demo } & 0.106311 & 0.080322 & 0.746024 \\
\hline $\begin{array}{l}\text { solution coverage: } \\
\text { solution consistency: }\end{array}$ & $\begin{array}{l}0.479316 \\
0.786551\end{array}$ & & & \\
\hline \multicolumn{5}{|c|}{ a no counterfactuals / logical remainders included } \\
\hline
\end{tabular}

Table A27 Parsimonious solution for integration ${ }^{\mathrm{a}}$

\begin{tabular}{|llll|}
\hline $\begin{array}{l}\text { frequency cutoff: } 1.000000 \\
\text { consistency cutoff: } 0.706399\end{array}$ & raw coverage & unique coverage & consistency \\
\hline colonial & 0.577406 & 0.476568 & 0.766667 \\
gdp* urban & 0.164232 & 0.063395 & 0.743981 \\
\hline $\begin{array}{l}\text { solution coverage: } \\
\text { solution consistency: }\end{array} \quad 0.640801$ & & & \\
\hline a & 0.758553 & & \\
\hline
\end{tabular}


Robustness-check: urbanization instead of metropolization, outcome resurgence Necessary conditions

Table A28 Analysis of necessary conditions for resurgence and non-resurgence

\begin{tabular}{lcc|c|c}
\hline & \multicolumn{2}{c}{ Resurgence } & \multicolumn{2}{c}{ Non-resurgence } \\
\hline Condition & Consistency & Coverage & Consistency & Coverage \\
\hline Metropolization & 0.652673 & 0.776293 & 0.755261 & 0.736962 \\
$\sim$ Metropolization & 0.778849 & 0.795044 & 0.770738 & 0.645451 \\
Urbanization & 0.867305 & 0.680064 & 0.837187 & 0.538541 \\
$\sim$ Urbanization & 0.411488 & 0.754944 & 0.502644 & 0.756549 \\
\hline The “ “ represents the negation or the absence of the causal condition. & &
\end{tabular}

\section{Sufficient conditions}

Table A29 Complex solution for resurgence

\begin{tabular}{|c|c|c|c|c|}
\hline \multicolumn{2}{|c|}{$\begin{array}{l}\text { frequency cutoff: } 1.000000 \\
\text { consistency cutoff: } 0.855231\end{array}$} & \multirow{2}{*}{$\begin{array}{l}\text { raw coverage } \\
0.396031\end{array}$} & \multirow{2}{*}{$\begin{array}{l}\text { unique coverage } \\
0.191288\end{array}$} & \multirow{2}{*}{$\begin{array}{l}\text { consistency } \\
0.855231\end{array}$} \\
\hline demo* $\operatorname{gpd}^{*} \sim$ urban & & & & \\
\hline demo*gdp*urban & & 0.354601 & 0.149858 & 0.883528 \\
\hline $\begin{array}{l}\text { solution coverage: } \\
\text { solution consistency: }\end{array}$ & $\begin{array}{l}0.545889 \\
0.862490\end{array}$ & & & \\
\hline no counterfactu & logical remainders included & & & \\
\hline
\end{tabular}

Table A30 Parsimonious solution for resurgence

\begin{tabular}{|llll|}
\hline $\begin{array}{l}\text { frequency cutoff: } 1.000000 \\
\text { consistency cutoff: } 0.855231\end{array}$ & raw coverage & unique coverage & consistency \\
\hline$\sim$ demo & 0.422783 & 0.160539 & 0.836097 \\
$\sim$ urban & 0.411488 & 0.149244 & 0.754944 \\
\hline $\begin{array}{l}\text { solution coverage: } \\
\text { solution consistency: }\end{array} \quad 0.572027$ & & & \\
\hline a & 0.750962 & & \\
\hline
\end{tabular}


Robustness-check: including conflict, outcome resurgence

Necessary conditions

Table A31 Analysis of necessary conditions for resurgence and non-resurgence

\begin{tabular}{lc|c|c|c}
\hline & \multicolumn{2}{c|}{ Resurgence } & \multicolumn{2}{c}{ Non-resurgence } \\
\hline Condition & Consistency & Coverage & Consistency & Coverage \\
\hline Conflict & 0.736139 & 0.871754 & 0.853109 & 0.828813 \\
$\sim$ Conflict & 0.855444 & 0.876523 & 0.867994 & 0.729637 \\
\hline
\end{tabular}

The " $\sim$ " represents the negation or the absence of the causal condition.

\section{Sufficient conditions}

Table A32 Complex solution for resurgence

\begin{tabular}{|llll|}
\hline $\begin{array}{l}\text { frequency cutoff: } 1.000000 \\
\text { consistency cutoff: } 0.872791\end{array}$ & raw coverage & unique coverage & consistency \\
\hline demo* metro & 0.744431 & 0.744431 & 0.837604 \\
\hline & & & \\
solution coverage: & 0.744431 & & \\
solution consistency: & 0.837604 & & \\
\hline a $\quad$ no counterfactuals / logical remainders included & & \\
\hline
\end{tabular}

Table A33 Parsimonious solution for resurgence

\begin{tabular}{|llll|}
\hline $\begin{array}{l}\text { frequency cutoff: } 1.000000 \\
\text { consistency cutoff: } 0.872791\end{array}$ & raw coverage & unique coverage & consistency \\
\hline$\sim$ metro & 0.778849 & 0.778849 & 0.795044 \\
\hline solution coverage: $\quad 0.778849$ & & \\
solution consistency: $\quad 0.795044$ & & \\
\hline a & & & \\
\hline \multicolumn{2}{|l|}{ all counterfactuals/ logical remainders included } & & \\
\hline
\end{tabular}




\section{Truthtable. Model 2(including ODA as forth condition)}

Table A34 Truth table for constitutional resurgence

\begin{tabular}{|c|c|c|c|c|c|c|c|c|c|}
\hline Democracy & Metropolization & Development & Aid & $\begin{array}{l}\text { Number } \\
\text { of cases }\end{array}$ & Resurgence & $\begin{array}{c}\text { Raw } \\
\text { consistency }\end{array}$ & $\begin{array}{c}\text { PRI } \\
\text { consistency }\end{array}$ & Product & Countries \\
\hline 1 & 0 & 1 & 0 & 9 & & 0.844118 & 0.538038 & 0.552617 & $\begin{array}{l}\text { Angola, Botswana, Chad, Equatorial Guinea, Ghana, Guinea, } \\
\text { Lesotho, Mauritania, Mozambique }\end{array}$ \\
\hline 1 & 1 & 1 & 1 & 6 & & 0.873422 & 0.571921 & 0.585948 & Burkina Faso, Kenya, Malawi, Namibia, South Africa, Swaziland \\
\hline 1 & 1 & 0 & 0 & 6 & & 0.805882 & 0.460525 & 0.462167 & Comoros, Djibouti, Mali, Niger, Senegal, Togo \\
\hline 1 & 0 & 0 & 1 & 6 & & 0.893158 & 0.673999 & 0.693514 & $\begin{array}{l}\text { Burundi, Cote d'Ivorire, Central African Republic, Ethiopia, } \\
\text { Gabon, Zimbabwe }\end{array}$ \\
\hline 1 & 1 & 1 & 0 & 4 & & 0.839229 & 0.521372 & 0.521963 & Guinea-Bissau, Nigeria, Sudan, Zambia \\
\hline 1 & 1 & 0 & 1 & 3 & & 0.85767 & 0.539057 & 0.556369 & Cameroon, Democratic Republic Congo, Sierra Leone \\
\hline 1 & 0 & 0 & 0 & 3 & & 0.856527 & 0.555212 & 0.559332 & Congo, Madagascar, Tanzania \\
\hline 1 & 0 & 1 & 1 & 2 & & 0.906426 & 0.692499 & 0.692499 & Rwanda, Uganda \\
\hline 0 & 1 & 1 & 1 & 1 & & 0.914866 & 0.671392 & 0.694571 & Eritrea \\
\hline 0 & 0 & 1 & 0 & 1 & & 0.897596 & 0.626614 & 0.628911 & Gambia \\
\hline 0 & 1 & 1 & 0 & 0 & log remain & & & & \\
\hline 0 & 1 & 0 & 1 & 0 & log remain & & & & \\
\hline 0 & 1 & 0 & 0 & 0 & log remain & & & & \\
\hline 0 & 0 & 1 & 1 & 0 & log remain & & & & \\
\hline 0 & 0 & 0 & 1 & 0 & log remain & & & & \\
\hline 0 & 0 & 0 & 0 & 0 & log remain & & & & \\
\hline
\end{tabular}




\section{Necessary conditions. Model 2}

Table A35 Analysis of necessary conditions for resurgence and non-resurgence

\begin{tabular}{lcc|cc}
\hline & \multicolumn{2}{c}{ Resurgence } & \multicolumn{2}{c}{ Non-resurgence } \\
\hline Condition & Consistency & Coverage & Consistency & Coverage \\
\hline ODA & 0.750115 & 0.806032 & 0.739915 & 0.652266 \\
$\sim$ ODA & 0.676390 & 0.760193 & 0.779968 & 0.719155 \\
\hline The " “" represents the negation or the absence of the causal condition. \\
\hline
\end{tabular}

\section{Sufficient conditions. Model 2}

Table A36 Complex solution for resurgence

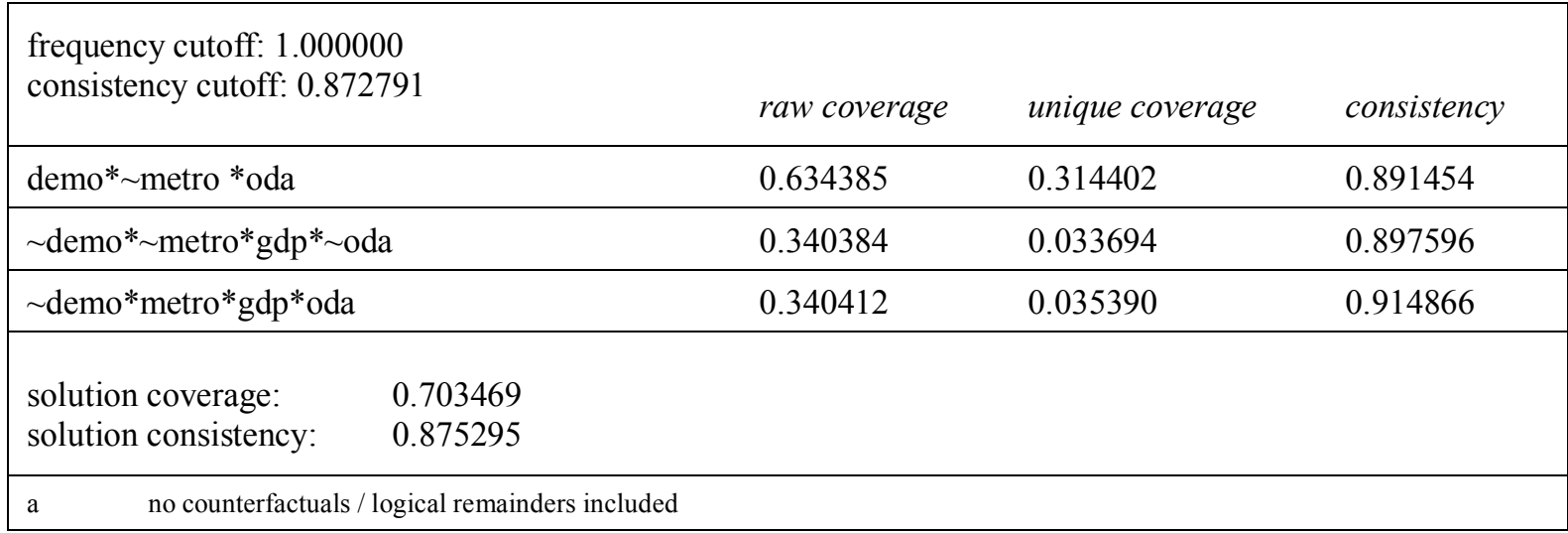


Table A37 Parsimonious solution for resurgence

\begin{tabular}{|c|c|c|c|c|}
\hline \multicolumn{2}{|c|}{$\begin{array}{l}\text { frequency cutoff: } 1.000000 \\
\text { consistency cutoff: } 0.893158\end{array}$} & \multirow{2}{*}{$\begin{array}{l}\text { raw coverage } \\
0.656263\end{array}$} & \multirow{2}{*}{$\begin{array}{l}\text { unique coverage } \\
0.285522\end{array}$} & \multirow{2}{*}{$\frac{\text { consistency }}{0.890278}$} \\
\hline$\sim$ metro* oda & & & & \\
\hline$\sim$ demo & & 0.422783 & 0.052042 & 0.836097 \\
\hline $\begin{array}{l}\text { solution coverage: } \\
\text { solution consistency: }\end{array}$ & $\begin{array}{l}0.708305 \\
0.834969\end{array}$ & & & \\
\hline
\end{tabular}

\section{Robustness-check: excluding the condition democratization}

Table A37 Model 2: Complex and parsimonious solution resurgence ${ }^{\mathrm{a}}$

\begin{tabular}{|c|c|c|c|c|}
\hline consistency cutott: 0 . & & raw coverage & unique coverage & consistency \\
\hline$\sim$ metro*oda & & 0.656263 & 0.656263 & 0.890278 \\
\hline solution coverage: & 0.656263 & & & \\
\hline solution consistency: & 0.890278 & & & \\
\hline
\end{tabular}

